Maurer School of Law: Indiana University

Digital Repository @ Maurer Law

2012

\title{
Academic SAILERS: The Ford Foundation and the Efforts to Shape Legal Education in Africa, 1957-1977
}

Jayanth K. Krishnan

Indiana University Maurer School of Law, jkrishna@indiana.edu

Follow this and additional works at: https://www.repository.law.indiana.edu/facpub

Part of the Legal Education Commons

\section{Recommended Citation}

Krishnan, Jayanth K., "Academic SAILERS: The Ford Foundation and the Efforts to Shape Legal Education in Africa, 1957-1977" (2012). Articles by Maurer Faculty. 795.

https://www.repository.law.indiana.edu/facpub/795

This Article is brought to you for free and open access by the Faculty Scholarship at Digital Repository @ Maurer Law. It has been accepted for inclusion in Articles by Maurer Faculty by an authorized administrator of Digital Repository@ Maurer Law. For more information, please contact rvaughan@indiana.edu. 


\title{
Academic SAILERS: The Ford Foundation and the Efforts to Shape Legal Education in Africa, 1957-1977
}

by JAYANTH K. KRISHNAN*

\begin{abstract}
This study examines a major law-and-development project in Africa undertaken by the New York-based Ford Foundation in the decades following the Second World War. By the 1960s, many countries in Africa freed themselves of colonial rule, and Ford eagerly sought to assist these newly emerging states in the nation-building process. One area towards which Ford contributed considerable resources was legal education. Labeling its program "SAILER"-or the Staffing of African Institutions of Legal Education and Research-Ford engaged in a range of initiatives, including sending American lawyers to teach in several different African countries and bringing Africans to law schools in the United States to study.
\end{abstract}

* Professor of Law and Charles L. Whistler Faculty Fellow, Indiana University Maurer School of Law. The author currently serves as the director for a separate Ford Foundation project examining the lower courts in India. He wishes to express his gratitude to the Ford Foundation for access to its historical archives. Also, for their assistance at various points of this project, the author thanks: Richard Abel, Ernest Abotsi, Elizabeth Bainbridge, John Bainbridge Jr., Kevin Brown, David Brownwood, Kaikhosrou Framji, Paolo Galizzi, Thomas Geraghty, Samuel Gyandoh, Jeremy Harrison, Frederick Hitz, Quintin Johnstone, Ajay Mehrotra, Chi Mgbako, Fali Nariman, Idelle Nissilla-Stone, Uzoamaka Nzelibe, Ruth Okediji, Christian Okeke, Vernon Palmer, James Paul, Lauren Robel, Peter Sand, Ann Seidman, Robert Seidman, Peter Sevareid, Peter Strauss, Francis Sutton, Susan Tanner, Danny Thiemann, Patrick Thomas, Cliff Thompson, and Terry Wood-Lavine. The author also expresses his gratitude to the lawyers, judges, educators, law students, and government officials who were interviewed in Ethiopia, Ghana, and Nigeria. (Upon request, their identities have been protected.) For their institutional support, the author thanks the University of Addis Ababa Law Faculty, the University of Ghana (Legon) Law Faculty, the Ghana School of Law, the University of Lagos Law Faculty, and the Nigerian Law School. This project was kindly funded by a grant from the Office of Vice-Provost for Research, Indiana University-Bloomington. 
The paper here evaluates this Ford initiative by relying primarily on three sources of original data: a review of all of Ford's archival documents on SAILER; interviews with former affiliates of SAILER residing in the United States; and archival research and interviews conducted in Africa during parts of 2010 and 2011. As the findings reveal, the story of this project is more complicated than the conventional wisdom might suggest. To begin, SAILER was not a single, monolithic program, nor was its mission to advance some grand Cold War, American foreign policy objective. Furthermore, the Africans with whom SAILER-officials worked were not all desperately yearning for assistance from the United States; many were sophisticated individuals simply interested in finding ways to enhance the rule of law in their respective countries. SAILER thus was seen as one potential vehicle for achieving this goal. And importantly, the attitudes of, and strategies employed by, those involved with SAILER-both in the United States and in Africa-were not static; they were nuanced and they evolved throughout the course of the project. By 1977, SAILER officially ended, but as this study concludes, the reasons were layered, and they related to contextual factors within Africa as much as to the internal decisions within Ford itself.

\section{INTRODUCTION}

- During the 1960s, the United States witnessed a series of defining moments, including the historic Civil Rights Movement, tragic political assassinations, and the rapid escalation of involvement in Vietnam. According to historians Maurice Isserman and Michael Kazin, those on the left and the right in this tumultuous decade "hotly disputed the morality of their opponents' values, language, and behavior and differed sharply and, at times, violently about how to build a society of individuals at peace with themselves and the rest of the world." ${ }^{1}$ In another part of the world-Africa - the 1960s similarly served as a pivotal period for a great many people who had been challenging colonial norms and seeking to pave new

\footnotetext{
1 See Maurice Isserman \& Michael Kazin, America Divided: The Civil War of the 1960s,
} 293 (2000). 
futures. In 1960 alone, seventeen African countries gained their freedom, and between 1961 and 1970 another fifteen followed suit. $^{2}$ The vast majority of these African states had as their rulers either Britain or France, with other Europeans exercising influence elsewhere as well. ${ }^{3}$

The developments occurring in Africa did not go unnoticed among interested observers in the United States. At the New Yorkbased non-profit organization, the Ford Foundation, officials had begun taking a serious interest particularly in Anglo-phonic Africa. Ford's traditional mission had been to provide financial resources and human capital to governments and civil society activists for the purposes of improving political stability, access to justice, and economic and social welfare. ${ }^{4}$ Given the linguistic ability to work in Anglo-phonic Africa, Ford policymakers started to contemplate how best to offer assistance in meaningful ways that would also mesh with the Foundation's agenda.

One area that soon became of focus was legal education. Dating back to the mid-1950s, Ford had privileged legal education and had funded "cooperative programs" 5 between American and foreign law schools in countries like Turkey, Egypt, Pakistan, West Germany, and India. ${ }^{6}$ Ford, during the '50s, also financially supported foreign students and foreign academics with fellowships to visit law schools in the United States; and there was funding provided for delegationexchanges between American lawyers and foreign bar associations. ${ }^{7}$ The theory behind Ford's legal education initiatives was simple: for these former colonies that now were free, strong legal systems were required in order for democracy to flourish. To that end, there needed to exist educational institutions that rigorously trained law

\footnotetext{
${ }^{2}$ See Chronological List of Independence Dates for Africa, AfRICAN HISTORY: EXPLORE THE HiSTORY OF AFRICA, http://africanhistory.about.com/library/timelines/blindepen denceTime.htm (last visited Nov. 18, 2011).

${ }^{3} I d$.

${ }^{4}$ See Mission Statement, FORD FOundaTION, http://www. fordfound.org/about-us/ mission (last visited Nov. 18, 2011).

${ }^{5}$ See Don Price, Special Report to the Officers: International Legal Studies (Oct. 16, 1955) (report on file with author); see also Jayanth K. Krishnan, Professor Kingsfield Goes to Delhi: American Academics, the Ford Foundation, and the Development of Legal Education in india, 46 AM. J. LEGAL HIst. 447, 450 (2004).

${ }^{6} / d$. at both cites.

${ }^{7} / d$ : at both cites.
} 
students to enter the legal profession with the necessary skills and values to uphold the rule of law. And with a vibrant legal profession and a democratic system of government, the likelihood of these societies experiencing greater economic prosperity only increased.

This "law-and-development" model, as it soon came to be known, was one that Ford followed into the 1960 s and $1970 \mathrm{~s}^{8}{ }^{8} \mathrm{It}$ also served as the basis for its legal involvement in Africa. In 1962, Ford officially launched an initiative known as the Staffing of African Institutions of Legal Education and Research-or SAILER. The stated purpose of SAILER was to financially support law schools in African countries: As importantly, it was to aid those governments that made "an express request for assistance ... . [and] to assist only those institutions where SAILER teachers would be welcome and where their teaching and research would add special dimensions or fill vital needs." 9 These SAILER-teachers would be comprised of lawyers, law professors, and recently-minted law graduates, mainly from the United States. The duration of stay for these teachers was not inconsequential. The project "urged that each teacher contemplate a minimum assignment of two years," 10 with the idea being that the Americans were supposed to help not just train good lawyers but also immerse themselves fully within the communities in which they worked.

So how did the SAILER project fare? That is the question this article seeks to address. Although SAILER was most prominent during the 1960s, it was not officially discontinued until 1977, and its effects can be seen still today. This article evaluates the history, performance, and influence of this Ford-Africa project. Along with a review of the existing literature on this subject, the article relies on three sources of original data. First, the Ford Foundation in New York City granted the author unfiltered access to all of its SAILERrelated documents (spanning several hundred pages). Second, over the course of several months in 2010 and 2011, the author inter-

\footnotetext{
${ }^{8}$ For a discussion of this point on law and development, see Thomas F. Geraghty \&. Emmanuel K. Quansah, African Legal Education: A Missed Opportunity and Suggestions for Change: A Call for Renewed Attention to a Neglected Means of Securing Human Rights and Legal Predictability, 5 Loy. U. CHI. INT'L L. REV. 87, 93 (2007).

${ }^{9}$ See John S. Bainbridge, The SAILER Project: 1962-1967, Ford Foundation Document 7 (July 1967) (on file with author). See generally JAMES A. GARDNER, LEGAL IMPERIALISM: AMERICAN LAWYERS AND FOREIGN AID IN LATIN AMERICA, 43-50; 211 12 (1980).

${ }^{10} / d$. at 8 (although also noting that exceptions could be made for one vear or less).
} 
viewed numerous American lawyers and American law professors who were SAILER-participants; interviews were also conducted with surviving Ford officials who were instrumental in envisioning and administering SAILER. Third, during the summer of 2010, the author traveled to Africa - in particular, to Ethiopia, Ghana, and Nigeria where SAILER had a pronounced presence. ${ }^{11}$ (The author then returned to Nigeria in May 2011.) In each of these countries, interviews were conducted with law professors, lawyers, judges, and other legal professionals-many of whom were SAILER-students. These data offer varied, nuanced, and; occasionally, critical perspectives on SAILER.

The thesis of this article is that, for what it endeavored to accomplish, SAILER achieved many of its goals. Moreover, it is helpful to view SAILER within the framework of Ford's other major law-anddevelopment project that was ongoing during this same period in India. Some years back this author published a detailed study of the Ford-India program. ${ }^{12}$ As the findings from that research reveal, Ford's India policymakers were intent on bringing an American-style legal educational model to cities like Kolkata, Mumbai, Delhi, Varanasi, and Chennai. ${ }^{13}$ To that end, Ford devoted money and other resources to Indian law schools in the hopes that they might adopt the American law school approach. ${ }^{14}$. Yet, as the American consultants (mainly American law professors) whom Ford hired to evaluate its program observed, this plan was flawed from the start. ${ }^{15}$ Ford officials, according to the consultants, had little knowledge of South Asia, nor were they sensitive to the cultural, historic, socio-economic, political, and legal differences with the United States, which made the wholesale incorporation of an American law school pro-

11 There were many other African countries in which SAILER was involved, including Kenya, Lesotho, Liberia, Malawi, Morocco, Senegal, Sudan, Tanzania, Uganda, Zaire, and Zambia. See John S. BaInBRIDGe, Study AND TEACHING of LaW IN AfRICA 178-179 (1972). Nigeria, Ghana, and Ethiopia were selected because a larger percentage of SAILER teachers worked in these countries than most of the others. And, logistically, these three countries were simply more accessible in terms of pursuing the fieldwork than most of the others. This point will be discussed in the ensuing sections.

12 See Krishnan, supra note 5.

13 ld.

14 Id.

$15 / d$. 
totype into India an all but impossible task. ${ }^{16}$ Ultimately; Ford abandoned these specific efforts by the early 1970 s. $^{17}$

In contrast, though, SAILER was differently conceived. As Section One of this article shows, the imagination of SAILER was derived from a set of entrepreneurial, anthropologically-attuned, and educationally focused Ford innovators and university-based legal scholars. ${ }^{18}$ Although many of these individuals were by birth Americans, by academic and policymaking orientation they aspired to be Africanists, who would eventually spend several years of their lives living in different parts of Africa. After Section One outlines this blueprint of SAILER, Section Two proceeds to examine how the program functioned in Africa, in general.

Section Three then looks at what occurred in three of SAlLER's highly invested countries: Ethiopia, Ghana, and Nigeria. The documents from Ford reveal a host of proud similarities and successes that emerged from the SAILER-efforts within these three places. But these papers, together with interviews from a range of former American and African SAILER-participants, highlight the differences and nuances that served as challenges and frustrations to those in New York and to those on the ground in the three countries. The Section ends by discussing how macro-political factors resulted in a shift in focus of the SAILER project by the late 1960 s.

${ }^{16} / d$. For a valuable and important set of insights into how Western foreign-aid, writ large, has proven to be problematic, see WILLIAM EASTERLY, THE WHITE MAN'S BURden: Why the West's Efforts to Aid the Rest Have Done So Much lll and So LitTle Good (2006).

${ }^{17}$ See Krishnan, supra note 5 . It is also important to situate Ford's SAILER program with other activities in which it was involved during this time as well as other on-going macro developments. For example, there was Ford's Foreign Area Fellowship Program. Towards the end of the 1960s and through the 1970s, Ford devoted a great deal of time and resources to the Council for Legal Education and Professional Responsibility (CLEPR), which was an initiative to inculcate clinical training into American law schools. In addition, there was the passage of the 1958 National Defense and Education Act, which funded area and language studies. During the 1960s, the African Studies Association grew as well, and universities saw a growth in African studies courses and programs. Great thanks to Professor Richard Abel for highlighting these crucial contextual points. Author correspondence with Abel (Aug. 16, 2011). See generally GARDNER, supra note 9.

${ }^{18}$ As will be seen, one of these officials, Theresa A. Wood, while working closely with Ford and other Ford policymakers, was officially an employee of, first, the independent Institute of International Education, and then of the International Legal Center, which although was a Ford creation too, was independent of Ford for official documentation purposes. 
The final section focuses on how, starting in 1967, Ford changed its strategic emphasis from sending Americans abroad towards instead bringing law students and legal professionals from Africa to the United States. Ostensibly this move was made to enhance educational opportunities for Africans. As it turned out, however, once in the United States the Africans, like they had in Africa, educated the Americans in important ways. Otherwise put, the instructional arrows here pointed in two directions - with the Americans providing substantive research and pedagogical opportunities to the Africans, but with the Africans teaching their counterparts a number of valuable lessons as well.

The findings below, thus, showcase two points. First, the American SAILER-teachers did not travel to Africa with the conscious intent of engaging in a new form of colonialism. In fact, the Americans understood that many of the African judges, lawyers, students, and teachers they encountered had superior credentials (from places like Oxford and Cambridge) and first-rate legal minds. Second, contrary to the conventional wisdom, African leaders actually invited the Americans to participate in the process of improving legal education. However, once the SAILER-participants arrived they received important advice and input from their African hosts. In sum, for those who are quick to label such law-and-development projects in one blunt fashion or another, the story below illustrates that, at least for SAILER, a proper analysis requires recognizing that these cross-national relationships can be complicated, subtle, and often non-linear.

\section{THE DEVELOPMENT OF THE SAILER PROJECT}

\section{A. The Initial Planning}

Prior to the establishment of the Ford Foundation in 1936, the two major American philanthropic organizations that existed were the Carnegie Corporation and the Rockefeller Foundation. ${ }^{19}$ By 1950, Ford shifted its headquarters from Michigan to New York and

19. Carnegie was founded in 1911, Mission and Vision, CARnEgie Corporation of NEW YORK, http://carnegie.org/about-us/mission-and-vision (last visited Nov. 18, 2011), and its institutional colleague, the Carnegie Foundation, in 1905. CARNegle FOUNDATION FOR THE ADVANCEMENT OF. TEACHING http://www.carnegiefoundation.org (last visited Nov. 18, 2011); Rockefeller was founded in 1913, THE ROCKEFELLER FOUNDATION WWW.rockefellerfoundation.org (last visited Nov. 18, 2011). 
refocused its mission towards international development; in doing so, it unilaterally changed the landscape of large-scale American philanthropy. One main reason was that Ford simply possessed so much more money than its competitors. ${ }^{20}$ But while it had greater financial capacity, the reputation of Ford, especially early-on, came under great scrutiny. Aside from critics decrying it as an arm of the United States government and as an exporter of American colonialism, its wealthy founder, Henry Ford, was an open anti-Semite, whose prejudices had long been documented. ${ }^{21}$ Still, the Ford Foundation then-and to this day-took great pains to emphasize its non-profit independence from the Motor Company, its humanitarian mission, and its sole desire to "strengthen democratic values, reduce poverty and injustice, promote international cooperation, [and] advance human achievement." 22 Today it cites its "nearly \$16 billion in grants distributed worldwide" 23 as central evidence of its commitment to its mandate.

In terms of its specific work relating to Africa and legal education, the archival documents suggest that the planning for engaging the continent began soon after Ghana gained its independence from Britain in 1957. The Ghanaian government approached Ford and proposed establishing a law school "scheme for the training of lawyers with qualifications suitable for conditions in Ghana today." 24 The

\footnotetext{
${ }^{20}$ Interview with Francis Sutton, an expert on American philanthropy and a highranking and long-time official at the Ford Foundation who, as will be discussed, played an instrumental role in the SAILER project (Sept. 27, 2010). For a key historical overview of American philanthropy, see Mark Sidel, Law, Philanthropy, and Social Class: Variance Power and the Battle for American Giving, 26 U.C. DAVIS L. REV. 1145 (2003).

${ }^{21}$ For a selected sample of works discussing Fords anti-Semitism, see NeIL BALDWin, Henry Ford and the Jews: The Mass Production of Hate (2001); Douglas Brinkley, Wheels for the World: Henry Ford, His Company, and a Century of Progress, 1903-2003 (2003); Max Wallace, The American Axis: Henry Ford, Charles lindbergh, And the Rise OF THE THIRD REICH (2003). See also Victoria Saker Woeste, Suing Henry Ford: America's First Hate Speech Case, AMERICAN BAR FoundaTION, http://www.americanbar foundation.org/research/project/19 (last visited Nov. 18, 2011).

22 See Mission Statement, FORD FoundaTION, http://www.fordfound.org/about-us/ mission (last visited Nov. 18, 2011).

${ }^{23}$ See About Us, Ford. FoundaTION, http://www, fordfoundation.org/About-Us (last visited Nov. 18, 2011).

24 Proposal from the Ministry of Justice, ghana, to the ford foundation, Proviston OF LEgal EDUCATION IN GHANA, 2 (Feb. 12, 1958.) Note, on page 7 of this document it states that the law school would be set to open in November 1957; however,
} 
reaction by Ford was circumspect. The main Ford policymakers discussing this initiative via cables and memorandums included H.C.L. (Chris) Merillat, a long time Ford-India policymaker who was brought in to advise on the Ghana question. There was also Francis (Frank) $X$. Sutton, a sociologist with a Ph.D. from Harvard, who was serving as Ford's program associate for the Middle East and Africa. Overseeing the discussion was John Howard, the director of Ford's International Training and Research Program, who was another Harvard Ph.D. (albeit in chemistry), and who was also a lawyer with a J.D. from the University of Chicago.

In the summer of 1958, Howard dispatched Merillat first to Britain and then to Ghana to meet with a number of lawyers and scholars who were familiar with the Ghanaian legal education-landscape. ${ }^{25}$ In London, Merillat met with A.N. Allott, who "[m]ore than any other English scholar... [ [had] worked seriously on native customary law in Ghana and elsewhere in Africa." 26 Prior to the meeting, Allott had written to Merillat. Allott revealed his skepticism towards the Ghanaian government's plan. For one thing, it did not set out methods for developing three types of lawyers that independent Ghana needed: "(a) business lawyers, i.e., solicitors, of Ghanaian origin, (b) Ghanaian lawyers in central and local government ... . [and] (c) lawyers to staff the present superior and magistrates' courts, and the proposed local courts which will replace the existing native courts." ${ }^{27}$ For Allott, the proposed Ghanaian scheme was ad hoc and piecemeal in nature, and it did not address two additional concerns: how the government planned to tackle corrup-

subsequent documents show that the opening would be in fact set for November of 1958. See e.g., Memorandum, H.C.L. Merillat, Legal Education in Ghana (Aug. 15, 1958) [hereinafter Merillat, Legal Education] (on file with author) (noting that "the school will get underway this fall, probably in November").

${ }^{25}$ See Letter from H.C.L. Merillat to A.N. Allott, School of Oriental and African Studies, informing the latter of his plans (June 16, 1958) (on file with author).

${ }^{26}$ See Merillat, Legal Education, supra note 24. Note Allott founded the African law department at the School of Oriental and African Studies in London. Other early members of the faculty included: a South African expatriate, Neville Rubin, Eugene Cotran, who authored restatement-type works on Kenya, Henry Morris, a bureaucrat who had worked in Uganda, and James Read. Author correspondence with Professor Richard Abel (Aug. 16, 2011).

${ }^{27}$ See Letter from A.N. Allott to H.C.L. Merillat 1 (June 27, 1958) (on file with author). 
tion in the judiciary and legal profession; and how legal education would substantively equip the next generation of lawyers with the necessary skills to be leaders within this newly independent country. ${ }^{28}$ Notwithstanding Allott's opposition, ${ }^{29}$ Merillat met with supporters of the initiative in the United Kingdom, including twice with Ghanaian Attorney General Geoffrey Bing, Dr. R.H. Stoughton-who was to be the founding Principal at the proposed University College (UC) of Ghana, and J.H.A. Lang who had been tapped to serve on both the UC law faculty and as director of Ghanaian legal education..$^{30}$ (The UC was to be the American equivalent of an undergraduate institution with a program in law.) In Ghana, Merillat encountered several lawyers and judges, the most prominent being Chief Justice Arku Korsah. Both Ghanaian and English-educated, Korsah also served as head of the UC project. ${ }^{31}$ Bing, Stoughton, Lang, and Korsah all sought Ford funding and wanted a Ford-sponsored American law professor who could serve as a visitor on the UC faculty. ${ }^{32}$ As Merillat reported back to New York, he ultimately concluded that Ford "ought not to support directly the new 'Temporary' Scheme for rapid training of lawyers," 33 although he recommended that Ford fund an American professor to serve as a UC visitor. The visitor's focus would be on "the longer-run development of legal education and professional standards," ${ }^{34}$ including an emphasis on research and pedagogy.

28 Id. at 2 .

${ }^{29}$ See Merillat, Legal Education, supra note 24.

${ }^{30} / d$. at 3-4.

${ }^{31} / d$. Korsah, in subsequent years, gained international acclaim as he presided over the famous Kulungugu trial. (He was concurrently serving as Ghana's Chief Justice). In this case, five defendants were charged with the attempted assassination of President Kwame Nkrumah. Two were found guilty, but Korsah acquitted the remaining three on lack of evidence. The verdict so outraged Nkrumah that the president ousted Korsah from his post as Chief Justice. See infra text accompanying note 214 .

32 See Merillat, Legal Education, supra note 24, at 3-4.

${ }^{33} \%$ d. at 1 (emphasis in original). Note this quote is also found in an evaluation of SAILER by Robert Listenbee, see source cited infra note 291 at 9 , who wrote two reports for Ford in 1977. Listenbee's evaluations are discussed in detail in the conclusion of this paper.

${ }^{34}$ See Merillat, Legal Education, supra note 24 , at 3-4. It is also worthwhile to note that in addition to the people Merillat met in London and Ghana, a letter from him back to Ford, dated August 16, 1958, also states that in England he had ap- 
Merillat's in-depth reporting of the situation in Ghana to Ford did not dampen the spirits of those within the office who still sought to work in Africa. Frank Sutton was one such Ford official, who wanted to investigate the possibilities. Before coming to Ford in 1954, Sutton had been an Assistant Professor of Sociology and General Education at Harvard. ${ }^{35}$ At Ford, he was assigned to the Social and Behavioral Sciences wing but then was transferred to Africa, where he lived during much of the latter half of the $1950 \mathrm{~s}^{36}$ This experience shaped his world-view that the only way for democracy to take hold was if education was at the forefront of development efforts-including legal education. In September of 1958, Sutton wrote to Harvard Law. School Dean, Erwin Griswold, to see what Griswold thought about pursuing legal education projects in Ghana. Conceding that he knew little about this subject except from what he had "learned from Mr. [J.H.A.] Lang and Professor L.C.B. Gower in London" 37 a month before, Griswold nevertheless determined that "developing an appropriate program of legal education in Ghana would not be easy." 38

Despite not receiving the support it had wanted from Ford, the Ghana government proceeded to open the UC (with a law faculty) and subsequently established the Ghana Law School in Accra in January of $1959 .{ }^{39}$ (The Ghana Law School was to train UC graduates to pass the necessary professional examinations to become mem-

pointments with: Members of Parliament: Dingle Foot and Desmond Donnelly, Time Magazine reporter, Honor Balfour, Professor Jim Gower from the University. of London, Mark Allen, a Commonwealth Relations Officer, Sir. Ralph Hone, and David Williams, Editor of a series of West African publications. In Ghana, Merillat also met R.J.H. Pogucki (Lands Commissioner), F.H. Battcock (staff member of the Ghana Attorney General's Office), Mr. Rouse-Jones (government legal advisor), a Mr. Stainton (legislative aide), a Mr. Taylor (Secretary to Development Commission and to Standing Committee on Development), members of the Ghana Bar Association, and Peter and William Barry (both of the U.S. Embassy).

35 Interview with Francis Sutton (Dec. 7, 2010); see Ford Foundation Biography Sheet on Francis $X$. Sutton (on file with author).

${ }^{36} / d$. at both cites.

${ }^{37}$ See Letter from Erwin N. Griswold to Francis X. Sutton (Sept. 18, 1958) (on file with author).

$38 / d$.

${ }^{39}$ See Ghana School of Law, Excerpt from THE WESt African Press SurVey (Jan. 13, 1959) (on file with author). Note J.H.A. Lang was both head of the UC and of the Ghana School of Law. 
bers of the bar:) Believing that any future involvement by Ford in Ghana (and Africa widely) would depend upon receiving the imprimatur of academic experts, Sutton traveled to Cambridge, Massachusetts on January 28, 1959 to visit with the constitutional law scholar Arthur Sutherland. ${ }^{40}$ There, Sutton explained his vision of wanting Ford to be involved in African legal education, and in particular, how he thought that a strong system of federalism, if incorporated, could serve African states well, especially with respect to the task of imparting legal education. ${ }^{41}$ According to the records, Sutherland appeared quite supportive and encouraging of this idea. ${ }^{42}$

Still, Frank Sutton was a realist. As he stated in memos some years later, and then in two interviews in 2010, in the back of his mind he constantly worried about the prospects of democracy in Africa and the wisdom of trying to implement Western-American-based legal norms and legal education in this region..$^{43}$ Yet at the same time he was torn. He believed, especially given the number of sophisticated and learned Africans with whom he dealt, that there was a real desire among these educators and policymakers for reforming, modernizing, and stabilizing the rule of law. ${ }^{44}$ Therefore, proceeding as many intellectuals often do when they are conflicted, Sutton decided he and Ford needed to do more studying and deliberating on what steps to take next. The eventual result was the birth of SAILER.

\section{B. The Creation of the Program}

Another key Ford player in the 1950s who was examining the developments from on the ground-this time in Lagos-was J. Donald Kingsley. Like John Howard, Kingsley was a lawyer and Ph.D. (from Syracuse's well-regarded Maxwell School). He had held a teaching post at Antioch College and thereafter served in the federal gov-

\footnotetext{
${ }^{40}$ See Memorandum, Francis X. Sutton, Visit with Professor Arthur Sutherland, Harvard Law School (Jan. 28, 1959, dated Jan. 29, 1959) (on file with author).

41 Id.; interview with Francis Sutton (Dec. 7, 2010). Follow-up written correspondence with Sutton (Dec. 15, 2010).

42 See Sutton, supra note 40.

${ }^{43}$ Interview with Francis Sutton (Dec. 7, 2010); interview (Sept. 27, 2010); see also Francis X. Sutton, Memo to the Files (62-293) (Aug. 29, 1977).

${ }^{44}$ See sources cited supra note 43 . See also Francis X. Sutton, SAILER: A Retrospect in Changed Times, A Conference of Law Teachers Who Worked in Africa 2024 (Sept. 26-27, 1986) (on file with author).
} 
ernment and at the United Nations on a combination of infrastructure and educational projects. ${ }^{45}$ Kingsley came to Ford in 1958 and by the late summer of 1960, while in Nigeria, he was drafting a memo about how best to support "teacher training" 46 and a "National Library" 47 in the country. Kingsley's report, Sutton's continued interest, and Howard's leadership position prompted the three to conceive of two major conferences: the first in Lagos in January of 1961 followed by one at Yale Law School three months later.

The Lagos conference was a jointly-funded effort by Ford and the Nigerian government. ${ }^{48}$ The conference was also sponsored by the International Commission of Jurists, a non-partisan group of lawyers and judges that promoted (and continues to do so) the "implementation of international law and principles that advance human rights." 49 There were several objectives to the meeting that included devising ways: to strengthen the legal profession and the judiciary in Africa; to bridge-build among lawyers within various parts of Africa; and to collaborate professionally with legal practitioners from the international community..$^{50}$

Laurence M. Lombard, a Boston lawyer (who would later go on to serve as director of Dow Jones \& Company ${ }^{51}$ ), attended the conference and documented the proceedings for the American Bar Association (ABA) Journal. The vast majority of the 194 participants were from Africa, ${ }^{52}$ but Lombard's account reveals how dignitaries

45 See Ford Biography Sheet on J. Donald Kingsley (on file with author).

${ }^{46}$ See Ford Foundation Memo from J. Donald Kingsley, Lagos 16 (Aug. 22, 1960) (on file with author).

${ }^{47} .1 d$.

${ }^{48}$ See Laurence M. Lombard, African Conference on the Rule of Law Held at Lagos, Nigeria, in January, 47 A.B.A. J. 563 (1961) (noting that Ford contributed $\$ 54,000$ to the venture and the Nigerians added 10,000 pounds).

${ }^{49}$ See INTERNATIONAL COMMISSION OF JURISTS (ICJ), http://www.icj.org/default.asp? nodelD $=441$ \&langage $=1$ \&myPage=Overview (last visited Nov. 18, 2011).

50 See Promotional Material, International Commission of Jurists (Dec. 21, 1960), http://www.icj.org/default.asp?nodelD=349\&sessID=138345226@21214758164 \&langage=1\&myPage=Legal_Documentation\&id=23403.

${ }^{51}$ For a rather sloppily titled obituary, see Obituary: Lawrence (sic) M. Lomardo (sic), N.Y. Times (Sept. 1, 1985), http://www.nytimes.com/1985/09/01/us/lawrencem-lomardo.html.

52 See Lombard, supra note 48, at 563. 
from around the world were also present..$^{53}$ From the United States, there was an array of attendees, ranging from Professors Robert Bowie (Harvard), Thomas Frank (NYU), Fowler Harper (Yale), William Burnett Harvey (Michigan), Louis Schwartz and James C.N. Paul (both from the University of Pennsylvania), New York lawyer Eli Whitney Debevoise, Third Circuit Judge William Hastie, and ABA official Charles Rhyne. ${ }^{54}$ According to Lombard, the three-day conference was divided into three concurrently held plenary sessions where, because of his status, he "was free to move from one committee to another," 55 which allowed him to witness "when particularly controversial points were being discussed." 56 The subject matter of the three sessions focused on, respectively, the scope and limitations of government-power, the intersection of criminal law and human rights, and how lawyers and judges could best protect individual freedoms. ${ }^{57}$ As Lombard observed, these discussions occurred against the backdrop of the on-going racial discrimination in the southern part of Africa (Southern Rhodesia and South Africa) and the continued colonial rule in other parts of the continent. ${ }^{58}$ Not surprisingly, when such issues arose, so did considerable tension. But overall Lombard's report indicates that the meeting was "a great success," 59 with a prevailing intimation being that for legal progress to occur in Africa, democratic values had to be imparted within educational institutions.

The ensuing April 1961 Yale meeting (which was purposely much smaller) picked-up on this idea by bringing together scholars from universities that had faculty interest in Africa, including Columbia,

\footnotetext{
53 These included, for example, from Britain: Sir Patrick Devlin, Norman Marsh, and Gerald Gardiner; from India: ICJ President Vivian Bose (who was also a former Justice on the Supreme Court of India); as well as representatives from France, Canada, Denmark, and Germany. Id. at 563-64.

${ }^{54}$ Id. at 564 . Note Lombard does not make mention of James Paul, but Paul's own account does. See James C.N. Paul, Seeking the Rule of Law in Africa, 10 EXPERIENCE 21 (2000) (noting that "[a] trip to Lagos, Nigeria to attend a lavish international conference on the future of the "Rule of Law in Africa" helped to ignite .. . [his] interest" in the continent. See id. at 21).

55 Lombard, supra note 48 , at 564.

$56 / d$.

$57 / d$.

$58 / d$. at 565-67.

$59 / d$. at 567 .
} 
MIT, Pennsylvania, Rutgers, Syracuse, and Yale. There were also representatives from Britain (including A.N. Allott), Nigeria, East Africa, and the U.S. State Department. ${ }^{60}$ Following, in particular, Sutton's desire to learn by having advisors with different perspectives debate, the plan was to arrive at a strategy for how Ford might substantively and productively support legal education in this region. ${ }^{61}$

From Yale's end, two individuals-Assistant Dean Charles Runyon and an assistant professor from Britain, Robert B. Stevens-were in charge of moderating the seminar. ${ }^{62}$ The first order of business involved determining in what countries Ford should play a role. A decision was reached that Ghana, given its preexisting connections with Ford, would remain of focus. ${ }^{63}$ In addition, because of interest from respective African leaders, Ford would explore ways to assist Nigeria, Sierra Leone, the Central African Federation, and countries in East Africa. ${ }^{64}$ As Runyon and Stevens describe, the Yale conference resulted in recommendations that Ford proceed along several interrelated lines. For example, there was the strongly-held view that American educators simply needed to know more about Africa. As Ruynon and Stevens rightly noted, "the greatest handicap to effective American participation in the development of African legal education has been the absence of any accurate knowledge of" 65 Africa. For this reason, they urged Ford to financially support American scholars for extended, in-depth visits in order to gain greater

${ }^{60}$ See Minutes of African Law Meeting at Yale Law School (Apr. 21, 1961) (on file with author).

$61 \mathrm{ld}$.

62 ld.

${ }^{63}$ Charles Ruynon \& Robert Stevens, Memorandum on Legal Education in Africa (on file with author) There is no date on this document, but there is a date of May 2, 1961 in a cover letter from Stevens to Cliff Thompson, who too was at the Ford Foundation and would eventually go on to work extensively in Sudan, Ethiopia, and Zambia. Thompson, among his many other accomplishments, would serve as dean at several different U.S. law schools, including Wisconsin, Hawaii, Idaho, and Michigan State. He was also the third and final American dean of the Haile Selassie University in Addis Ababa, and he was a faculty member at the University of Zambia. See, Cliff Thompson Bio, UnIVERSITY of WISCONSIN LAW SCHOOL, http://law.wisc. edu/profiles/cfthomps@wisc.edu (last visited Nov. 18, 2011).

${ }^{64}$ See Runyon \& Stevens, supra note 63 , at 4 (noting also East Africa; at this time, was divided into Kenya, Uganda, and Tanganyika. In terms of education, a technical college was present in Nairobi, and a law faculty was planned for Dar es Salaam).

$65 \mathrm{ld}$. 
"information and understanding about the problems of legal education in Africa." 66 .

There were other recommendations as well. Through the establishment of fellowships, Ford could become more involved with American law school efforts to recruit African students, particularly from Anglo-phonic countries. ${ }^{67}$ Plus, although Runyon and Stevens recognized that " $[\mathrm{t}]$ he time for any American university to act as [an] adviser for an African one is somewhat premature," 68 hope existed for the time when Ford could serve as an eventual conduit. Indeed, in 1960 the prominent scholar. Max Rheinstein, from the University of Chicago, traveled on behalf of the Carnegie Corporation to several African law schools and had made a similar observation about the possibility of burgeoning American-African partnerships in the future. ${ }^{69}$ Finally, Ford could assist by providing much needed funding-opportunities for experts in African law-"a field which ha[d] been totally neglected until now"70courses at law schools in the United States.

From the Lagos and Yale conferences, great energy ensued. One person who was present at both meetings was James C.N. Paul, a thirty-five year old law professor at the University of Pennsylvania, who would become a seminal figure in the SAILER program. ${ }^{71}$ Paul and Runyon struck up a friendship, and during the summer of 1961 Runyon was able to secure funding for Paul from the Eisenhower Exchange Fellowship Program to travel to ten African countries over a six week period. ${ }^{72} \mathrm{~A}$ careful scholar who disdained "inside reports written by people who ... visit a place for only a few days and then write knowingly,"73 Paul was nonetheless commissioned to explore the status of legal education in mainly Anglo-phonic West and East

\footnotetext{
$66 / d$. at 5.

$67 / d$. at 5-6.

$68 / d$. at 6.

69 Id. at 5-7.

$70 \%$ at 8.

${ }^{71}$ See Paul, supra note 54; Minutes of African Law Meeting, supra note 60.

72 See Paul, supra note 54 at 21-22; see also James C.N. Paul, Memorandum: Developments in Legal Education in English Speaking Countries in West and East Africa (Aug. 1961) (on file with author).

${ }^{73}$ See Paul, Memorandum: Developments in Legal Education, supra note 72; at
} Preface. 
Africa and comment on what interested Americans could do to assist there. ${ }^{74}$

As he learned from his interactions with lawyers, judges, policymakers and academics, although each country had its own unique culture, history and traditions, there were common legal educational needs that had not been met by the colonial administrators. Paul was told that the next generation of African lawyers required training in private, commercial, transactional law. The education of future African lawyers, he repeatedly heard, also had to move away from the colonial approach of "doctrinal-and didactic-methods" 75 and embrace instead a more comprehensive law-and-public policy approach.

Paul returned to the United States ecstatic. He drafted a memo that outlined a model in which American legal educators could assist African law schools by employing the very best practices from the United States while remaining sensitive to the nuances of local, customary law and traditions that permeated each of the targeted countries. ${ }^{76}$ It was an ambitious plan, even one filled with great hubris - a concession Paul made four decades later. ${ }^{77}$

But Paul's conception of American involvement in Africa, versus, for example, how Ford was running its India legal education program at this same time, was qualitatively different and certainly more subtle. The main difference, of course, was that Paul proposed having Americans immersed in Africa, learning about the different societies, and serving not just as teachers but as students of their new environments. Runyon and Paul presented the latter's findings and proposal to Ford in the fall of 1961, and soon thereafter, Sutton, Howard, and other leaders in the Foundation decided to use it as the template for initiating a project that would be called Staffing of African Institutions of Legal Education and Research-SAILER. ${ }^{78}$

\footnotetext{
${ }^{74}$ As Paul describes, he "traveled to Senegal [a Franco-phone country], Liberia, Sierra Leone, Ghana, Nigeria, and across the continent to Sudan, Ethiopia, Somalia, and East Africa." See Paul, supra note 54, at 22.

$75 / d$. at 23.

${ }^{76}$ See Paul, Memorandum: Developments in Legal Education, supra note 72.

77 See Paul, supra note 54, at 23 (noting how "[l]ooking, back, I am somewhat ashamed of the arrogance that infected my enthusiasm. But by 1961 Africa had been 'discovered' by intellectuals, politicians and aid-givers; optimism overshadowed realism, and instant expertise was widely practiced.").

78 ld.
} 
The next step was that Ford needed someone to implement the blueprint - to operationalize in practice what had been developed on paper. In 1962, Ford hired John S. Bainbridge, an assistant dean from Columbia Law School, to head SAILER. ${ }^{79}$ A graduate of Harvard College and Columbia Law, Bainbridge served in World War II and then as a private lawyer until $1956 .{ }^{80}$ For the next six years, Bainbridge worked at Columbia on international programs until he was brought on by Ford in $1962 .{ }^{81}$ The following section details how Bainbridge devoted over a decade of his professional life to SAILER and the effects of his work on legal education in Africa:

\section{IMPLEMENTING SAILER}

\section{A. Moving Concretely to an Agenda}

John Bainbridge never saw himself as a prolific scholar or an abstract theoretician. At Columbia his success came from being a practical administrator, someone who conceived of law as an action-oriented instrument, particularly as it related to exposing students, faculty, and staff to the changing international landscape. He was also an individual whose passion came from working with people who wanted to make their lives better; and he brought this attitude to SAILER. To Bainbridge's detractors, though, his ambition smacked of imperialist arrogance; in fact, one of his biggest critics was within Ford itself, John Spencer, a program officer, who derisively referred to him as "Cecil" (as in Cecil Rhodes) and lampooned him as "one of the few empire builders left in the world." ${ }^{2}$

\footnotetext{
${ }^{79}$ See David Brownwood, John S. Bainbridge, 1915-2006 (Feb. 26, 2006) (personal letter on file with author).

${ }^{80}$ See Wolfgang Saxon, John S. Bainbridge, 90, Legal Educator for African Leaders, N.Y. TIMEs (Feb. 6, 2006) http://www.nytimes.com/2006/02/06/nyregion/06bain bridge.html.

$81 / d$.

${ }^{82}$ See Memorandum from John Spencer to Francis $X$. Sutton, SAlLER in Africa (Oct. 27, 1965) (on file with author). In a separate memo two months later to J. Donald Kingsley, Spencer once again critiques Bainbridge as "a long, rambling" speaker who thought about dropping SAILER from his portfolio as early as December 1965 so that he (Bainbridge) could "concentrate on providing legal advice to the President of Columbia" - another venture that Spencer saw as dilettanteesque by Bainbridge. See Memo from John Spencer to J. Donald Kingsley, [Subject: John Bainbridgel (Dec. 29, 1965) (on file with author).
} 
But to others who knew and worked intimately with Bainbridge, this was an unfair charge. As they stated, his main goal was to determine how best to deliver legal education to those who so requested, in an economically, pedagogically and culturally sensitive fashion. No documented evidence has been found to suggest that Bainbridge ever used SAILER to further American expansionism or American foreign policy goals. From the start, and then throughout the life of SAILER, supporters of Bainbridge noted that he repeatedly incorporated different points of views from different parts of the world, most importantly from Africa. As evidence, in January of 1962, Bainbridge helped to organize another conference, this time in Accra, Ghana, where he invited mainly Africans to discuss how best to begin the implementation of SAILER. ${ }^{83}$

The Africans, along with the American and British representatives who were present, concluded that because the latter was having difficulty filling teaching posts at their own law colleges in the United Kingdom, let alone enticing enough Britons to venture into the African legal academy, the Americans should be the primary foreign staff working on the continent with their counterparts. ${ }^{84}$ Upon the conclusion of the Ghana meeting, a follow-up session with several of these same participants occurred in March of 1962 at Ford headquarters in New York City. ${ }^{85}$ Here the agenda included finalizing the decision to have Ford fund a group of American lawyers who would spend extended periods of time as members of African law faculties. ${ }^{86}$

\footnotetext{
${ }^{83}$ See Bainbridge, THE SAILER ProJect, supra note 9 , at 3 . From the conference program, sixteen African countries were listed as having sixty-three representatives; the United States had eight representatives, Britain had three, New Zealand had one, and UNESCO had one. (Bainbridge notes though that it was "believed that not everyone listed attended the conference." BaINBRIDGE, supra note 11, at 174.).

${ }^{84}$ See Bainbridge, THE SAILER PROJECT, supra note 9, at 4.

${ }^{85} / d$. See also BAINBRIDGE, supra note 11 , at $174-77$ for a list of participants.

${ }^{85}$ Interestingly, a parallel project administered by the U.S. government was in its formative stages at this time as well. President John Kennedy's Peace Corps program was seeking to recruit lawyers who would travel to Africa and work in the same fashion as Ford's proposed initiative. At the behest of Harris Wofford, the deputy-director of the Peace Corps, James Paul returned to many of the African countries he had previously visited, but this time to explore how receptive local officials would be towards hosting U.S. government-funded lawyers. He later documented how he "was pleasantly surprised to become aware of numerous requests for volunteers to staff [a variety of different] positions ...." These included
} 
In June of 1962 , Ford made its first official grant to fund SAILER in the amount of $\$ 238,000 .{ }^{87}$ The grant was for a two-year term that could be renewed depending on the progress of the program. ${ }^{88}$ Bainbridge was formally named as director of SAILER. ${ }^{89}$. Ford had sponsored past initiatives on Africa; in 1960, it had provided a $\$ 106,000$ grant to the University of Khartoum to study the history of Sudanese law. ${ }^{90}$ It was funding two separate American university programs, one at MIT and the other at Syracuse, which involved sending Americans to Africa to work in positions of public administration as well as law teaching. ${ }^{91}$ But the SAILER grant was the widest in scope and most penetrating in terms of purpose. The objective was two-fold: to strengthen already existing law schools in countries like Ghana, Zaire, Somalia, Sudan, Tanzania, as well as in the Francophone country of Senegal; and to establish sound legal educational institutions in places where there was "scarcely the beginning of a professional group of African lawyers." ${ }^{2}$

The strategy for implementing SAILER was straightforward and came in three parts. First, there would be support for senior American legal scholars to travel and spend time on law faculties in Africa. These academics would work with Africans interested in develop-

working as academics, drafters on legislation, and as assistants on customary law projects. See Paul, supra note 54, at 23.

${ }^{87}$ See Ford Foundation, Program Action Memo (May 25, 1962); see also Bainbridge, THE SAILER PROJECT, supra note 9, at 4.

${ }^{88}$ See id. at both cites.

${ }^{89}$ See Bainbridge, THE SAILER PROJECT, supra note 9, at 5.

${ }^{90}$ See Request for Grant Action; Ford Foundation Memo 1 (Apr: 27, 1962) (on file with author).

91. Id.; see also Bainbridge, THE SAILER PROJECT, supra note 9, at 87 (noting how in Nigeria, at Ahmadu Bello University, "[a]ble expatriate teachers, not only from SAILER but from both Syracuse and MIT programs, have established the law faculty as a center of vigorous, independent scholarship.").

92 See Request for Grant Action, supra note 90 at 2. For an important scholar who has written on the Francophone law-and-developments in Africa, see JESWALD W. Salacuse, An Introduction to Law in French Speaking Africa l-II (1975) (note Salacuse also served as an advisor to Ford and as an Associate Director for the African Law Center. For information on the ALC, see infra note 185 . He also was involved in shaping the law faculties in the Sudan, Nigeria, and Zaire; see Jeswald Salacuse Bio, TUFts UnIVERSITY: THE FLETCHER SCHOOL, http://fletcher.tufts.edu/Fletcher-Direc tory/Find-Fletcher-People/Faculty\%20Profile?personkey=A4A09414-C9B2-46AC A926-2FF762BA71CA (last visited Nov. 18, 2011)). 
ing their research, writing, and scholarship skills. ${ }^{93}$ Second, SAILER would offer opportunities for "junior Americans" 94 - recent, "firstclass graduates of the best American law schools"95 - to serve as teaching fellows on African law faculties for up to two years. The idea here was that by having instructors who were closer in age to both the African students and the younger African faculty, the "junior Americans" might more easily relate to these colleagues, which in turn might spawn deeper professional relationships beyond the two-year visitor-ship. Third, for certain African law schools, the leadership of these institutions would be comprised of academics from the West who would be supported by SAILER-funding. ${ }^{96}$

Curiously, in none of the Ford papers was there serious mention of how problematic this SAILER-plan might be. There are likely two explanations for such an omission. One is that there was indeed "arrogance" 97 among the SAILER designers, especially among those caught up in the "nationalistic view that first-rate young lawyers from the U.S. could well prove their worth to many new governments in Africa." ${ }^{\prime 98}$ The Americans thus did not view themselves as anything but cooperative colleagues in what they perceived to be a noble cause. The other reason was that the Americans were primarily in contact with African leaders and educational officials who were sympathetic to the objectives of SAILER. Recall that Ford deliberately engaged only those African states that reached out to it for legal educational assistance. The story of James Paul's inaugural decanal appointment lends support for this position. As he noted in his reflections on SAILER:

Late in 1962, when I was working in my law school office at Penn, the phone rang; and after a lot of operator chatter I was connected with the Imperial Palace in Addis Ababa. My Ethiopian caller identified himself as the newly

\footnotetext{
${ }^{93}$ Request for Grant Action, supra note 90, at 2-3.

${ }^{94} / d$. at 3.

$95.1 d$.

${ }^{96}$ For example, at the Institute of Public Administration in Mpemba, Malawi, "an American law graduate [Vern Davidson was] ... in charge of the professional law training program." See Bainbridge, THE SAILER PROJECT, supra note 9, at 78. Similarly, James Beardsley led the law faculty at the University of Botswana, Lesotho, and Swaziland. $I d$. at $72 ;$ id. at 72 tbl.1. This point will be discussed in further detail when looking at the three case studies.
}

97 See Paul; supra note 54, at 23.

${ }^{98}$ Id. 
appointed president of the newly created Haile Selassie University. He said to me, "I am standing in the presence of His Imperial Majesty who commands - I mean requests $-I$ mean invites - you to come to Ethiopia to start a law school in His new university as its first dean. Will you come?"9g

Perhaps then, from the SAILER leadership's perspective, there was the assumption that the wishes of governmental and educational leaders reflected a wider consensus among the respective constituencies. If this were the case, there would have been little reason to anticipate resentment or backlash; however, as will be seen soon, in some instances such hostility boiled to the surface. Additionally, there was the belief among SAILER officials and African educational leaders (like those in attendance at the Accra conference) that a new approach towards legal education needed to be embraced. John A. Harrington and Ambreena Manji have uncovered how Lord Denning, one of Britain's most famous experts on legal education, advocated reforms in the 1950s and early $1960 \mathrm{~s}$ for Africa that were traditional and conservative. ${ }^{100}$ As Harrington and Manji describe, L.C.B. Gower-a Briton himself-was particularly opposed to Denning's position that African lawyers needed to be trained in the English vein where technical, practice-oriented skills were emphasized above all else. ${ }^{101}$ In contrast, for Gower and the other SAILER advocates, legal education had to include a breadth of courses where law and "non-law subjects [were] to be taught to degree students." 102 In other words, as will be discussed

99 ld. at 23-24.

100 See John A. Harrington \& Ambreena Manji, Mind with Mind and Spirit with Spirit: Lord Denning and African Legal Education, 30 J.L. \& Soc'y 376 (2003). For a classic piece on the differences between English and American legal education, see John H. Merryman, Legal Education Here and There: A Comparison, 27 STAN. L. Rev. 859 (1975); see also Andrew Boon \& Julian Webb, Legal Education and Training in England and Wales: Back to the Future? $58 \mathrm{~J}$. LEGAL EDUCATION 79 (2008) (citing also Merryman at 79).

${ }^{101}$ Harrington \& Manji, supra note 100, at 377-78, 383-84. Note, the authors do not discuss SAILER in particular but do mention the Ford Foundation and how the Americans had extensive, "superior resources"-much more than the Brits-to substantially impact legal education in Africa. See id. at 382.

$102 / d$. at 386. Two other prominent British academics who felt similarly to Gower were Professors Michael Zander and Geoffrey Bindman. In addition, the Committee on Legal Education in the United Kingdom, chaired by Lord Roger Ormrod, issued a report in 1971 that highlighted a number of suggestions for revamping British legal education. Such a move had been argued for by the likes of William Twining; 
next, autonomy from the bar, a liberal law and public policy curriculum, and academic entrepreneurialism-all anathemas to Denning-were promoted as the proper foundation for the new African law school model. ${ }^{103}$

\section{B. Beginning the Real Work}

By the time SAILER began its substantive tasks, towards the end of 1962, the British had all but conceded their diminishing influence over the future of African legal education. ${ }^{104}$ The Americans had more money, and interest in African academia in Britain was comparatively less than in the United States. ${ }^{105}$ Britons still maintained some presence on various African law faculties. ${ }^{106}$ But the SAILER program had the greater presence throughout the 1960 s. Consider Table 1, which provides three key points of information: the countries and institutions within them that hosted SAILER-teachers; the participants themselves; and the amount of funding allocated to these individuals during their first assignments in Africa. Several of these participants continued to stay on for subsequent assignments, with SAILER-support. (And note, while almost all of these individuals were Americans, a few were not.)

see William Twining, Pericles and the Plumber, 83 L.Q. Rev. 396 (1967). See Boon \& Webb, supra note 100, at 89-93. See also author correspondence with Professor Richard Abel (Aug. 16, 2011).

${ }^{103}$ Harrington \& Manji, supra note 100 , at 383-86. Note, in this article, the authors discuss how the British saw the American efforts on legal education to be part of a larger geopolitical method to combat Soviet influence in the region. This viewpoint, as will be discussed later, is one that was also shared by those Africans who opposed Ford's plans. However, nowhere is there evidence in the Ford documents that such motivation is what drove the SAILER-leadership.

${ }^{104} \mathrm{ld}$.

105 Id. at 382.

106 In particular, consider the famous legal theorist, William Twining, who was born in Uganda, spent time teaching in Khartoum and then Dar-es-Salaam between 1958 and 1965. See Raymundo Gama (Alicante), Interview with William Twining 1 (Jan. 10, 2010), http://www.ucl.ac.uk/laws/academics/profiles/twining/ALICANTEINTERVIEW10Jan2010.pdf (although as Twining himself notes, in terms of academic research and publications, he has "not written much about this [i.e., legal education in Africal, although it remains an important part of ... [his] background." Id. at 1 . 


\section{TABLE $1^{107}$}

SAILER Expenditures and Commitments during the Early Years

\begin{tabular}{|c|c|c|}
\hline $\begin{array}{l}\text { Staffing by Countries } \\
\text { \& Institutions }\end{array}$ & Personnel & $\begin{array}{l}\text { Money Committed } \\
\text { and Time Period }\end{array}$ \\
\hline $\begin{array}{l}\text { Longo: } \\
\text { Lovanium University }\end{array}$ & John Crabb & $\$ 15,552.83(10 / 1964-7 / 1966)$ \\
\hline $\begin{array}{l}\text { Ethiopia: } \\
\text { Haile Selassie University }\end{array}$ & $\begin{array}{l}\text { James C.N. Paul } \\
\text { Albert P. Blaustein } \\
\text { Steven Lowenstein } \\
\text { Robert A. Sedler } \\
\text { Thomas O. Rose }\end{array}$ & $\begin{array}{l}\$ 22,000(6 / 1963-6 / 1964) \\
\$ 6,100(5 / 1963-4 / 1964) \\
\$ 6,214.79(7 / 1963-7 / 1964) \\
\$ 11,004.78(8 / 1963-8 / 1964) \\
\$ 9,447.90(9 / 1963-8 / 1964)\end{array}$ \\
\hline $\begin{array}{l}\text { Ghana: } \\
\text { University of Ghana } \\
\text { Law Faculty }\end{array}$ & $\begin{array}{l}\text { William Burnett Harvey } \\
\text { Robert B. Seidman } \\
\text { Vern G. Davidson } \\
\text { Judith R. Thoyer } \\
\text { Michael E. Thoyer } \\
\text { Jeremy T. Harrison } \\
\text { David B. Bryson }\end{array}$ & $\begin{array}{l}\$ 44,138.48 \cdot(9 / 1962-2 / 1964) \\
\$ 13,000(1 / 1963-9 / 1964) \\
\$ 7,000(7 / 1963-8 / 1964) \\
\$ 4,721.90(7 / 1963-8 / 1964) \\
\$ 6,768.21(7 / 1963-7 / 1964) \\
\$ 7,500(8 / 1963-9 / 1964) \\
\$ 19,000(9 / 1967-9 / 1969)\end{array}$ \\
\hline $\begin{array}{l}\text { Kenya: } \\
\text { Kenya Institute of } \\
\text { Administration }\end{array}$ & Philip E. Durand & $\$ 36,500(7 / 1967-7 / 1969)$ \\
\hline $\begin{array}{l}\text { Lesotho: } \\
\text { University of Botswana, } \\
\text { Lesotho, and Swaziland }\end{array}$ & $\begin{array}{l}\text { James E. Beardsley } \\
\text { Vernon V. Palmer }\end{array}$ & $\begin{array}{l}\$ 22,700(7 / 1966-7 / 1968) \\
\$ 20,400(7 / 1967-7 / 1969)\end{array}$ \\
\hline $\begin{array}{l}\text { Liberia: } \\
\text { Louis Arthur Grimes }\end{array}$ & & \\
\hline Law School & $\begin{array}{l}\text { Eugene T. Herbert } \\
\text { Seymour S. Weisberg } \\
\text { L. Michael Hager } \\
\text { Charles C. Ruff } \\
\text { Gerald H. Zarr } \\
\text { Theodore Pärnall. } \\
\text { C. Dallas Sands }\end{array}$ & $\begin{array}{l}\$ 10,084.91(10 / 1962-1 / 1964) \\
\$ 4,936.85(10 / 1962-1 / 1964) \\
\$ 11,847.21(12 / 1963-12 / 1965) \\
\$ 15,634.93(12 / 1963-12 / 1964) \\
\$ 12.804 .22(3 / 1965-2 / 1967) \\
\$ 13,970(2 / 1967-2 / 1969) \\
\$ 8,353.11(6 / 1966-8 / 1966)\end{array}$ \\
\hline $\begin{array}{l}\text { Malawi: } \\
\quad \text { Institute of Public }\end{array}$ & & . \\
\hline Administration & $\begin{array}{l}\text { Simon A. Roberts } \\
\text { Vern G. Davidson } \\
\text { Philip E. Durand }\end{array}$ & $\begin{array}{l}\$ 6,723(12 / 1962-12 / 1964) \\
\$ 14,175.75(9 / 1964-10 / 1966) \\
\$ 9,253.26(8 / 1965-8 / 1966)\end{array}$ \\
\hline Vigeria: & & \\
\hline Lagos Law Faculty & $\begin{array}{l}\text { Andrew E.W. Park } \\
\text { Robert B. Seidman }\end{array}$ & $\begin{array}{l}\$ 2,520(10 / 1962-9 / 1964) \\
\$ 7,381.88(9 / 1964-9 / 1965)\end{array}$ \\
\hline Ife University & $\begin{array}{l}\text { O.R. Marshall } \\
\text { Jeremy T. Harrison } \\
\text { Frederick Hitz } \\
\text { Thomas A. Lamia }\end{array}$ & $\begin{array}{l}\$ 6,898.84(10 / 1963-9 / 1965) \\
\$ 13,405.46(10 / 1964-8 / 1966) \\
\$ 9,615.64(9 / 1964-9 / 1965) \\
\$ 5,812.99(9 / 1966-4 / 1967)\end{array}$ \\
\hline $\begin{array}{l}\text { Zaria, Ahmadu Bello } \\
\text { University, Institute of } \\
\text { Administration }\end{array}$ & $\begin{array}{c}\text { Stephen S. Weddle } \\
\text { David Carroll }\end{array}$ & $\begin{array}{l}\$ 12,478.96(7 / 1963-7 / 1964) \\
\$ 35,165.00(9 / 1965-7 / 1967)\end{array}$ \\
\hline
\end{tabular}


TABLE $1^{107}$ (Cont'd)

SAILER Expenditures and Commitments during the Early Years

\begin{tabular}{|c|c|c|}
\hline $\begin{array}{l}\text { Staffing by Countries } \\
\text { \& Institutions }\end{array}$ & Personnel & $\begin{array}{l}\text { Money Committed } \\
\text { and Time Period }\end{array}$ \\
\hline Nigeria: (cont'd) & Shirley C. Zabel & $\$ 15,000(9 / 1967-7 / 1968)$ \\
\hline $\begin{array}{l}\text { Sudan: } \\
\text { University of Khartoum } \\
\begin{array}{lll} \\
\end{array}\end{array}$ & $\begin{array}{c}\text { Robert A. Cook } \\
\text { Eugene V. Scoles } \\
\text { Cliff F. Thompson } \\
\text { Norman Penney } \\
\text { A.Thomas Hunt } \\
\text { Samuel J. Trueblood } \\
\text { David O. Brownwood } \\
\text { Carlyle W. Hall } \\
\text { Shirley C. Zabel }\end{array}$ & $\begin{array}{l}\$ 20,328.31(10 / 1962-11 / 1964) \\
\$ 22,451.60(7 / 1964-7 / 1965) \\
\$ 8,595.83(8 / 1964-8 / 1965) \\
\$ 27,403.35(7 / 1965-4 / 1966) \\
\$ 23,409.53(7 / 1965-6 / 1967) \\
\$ 11,106.75(7 / 1965-7 / 1966) \\
\$ 21,000(7 / 1966-8 / 1967) \\
\$ 11,500(7 / 1966-8 / 1967) \\
\$ 13,454.10(7 / 1966-6 / 1967)\end{array}$ \\
\hline $\begin{array}{l}\text { Tanzania: } \\
\text { University of East Africa, } \\
\text { University College }\end{array}$ & $\begin{array}{l}\text { Wolfgang Friedmann } \\
\text { Charles W. Quick } \\
\text { Thomas Franck } \\
\text { Conrad L. Kellenberg } \\
\text { lan R. Macneil } \\
\text { Jack A. Hiller } \\
\text { William Whitford }\end{array}$ & $\begin{array}{l}\$ 1,667.60(7 / 1963-8 / 1963) \\
\$ 4,900.38(9 / 1963-9 / 1964) \\
\$ 6,617(7 / 1964-9 / 1964) \\
\$ 2,295.20(9 / 1964-9 / 1965) \\
\$ 22,000(9 / 1965-7 / 1967) \\
\$ 23,500(7 / 1966-7 / 1968) \\
\$ 8,500(7 / 1967-7 / 1969)\end{array}$ \\
\hline $\begin{array}{l}\text { Zambia: } \\
\text { University of Zambia, } \\
\text { Lusaka }\end{array}$ & $\begin{array}{l}\text { Cliff F. Thompson } \\
\text { Thomas A. Lamia }\end{array}$ & $\begin{array}{l}\$ 32,000(1 / 1967-1 / 1969) \\
\$ 9,800(4 / 1967-12 / 1967)\end{array}$ \\
\hline
\end{tabular}

*Not included: Inez Smith who worked at EDNA in Congo and Allen Farnsworth and John $M$. Hazard, who worked in Senegal. According to the SAilLER documents, no SAlLER funding was allocated to them.

In 1967, John Bainbridge completed a five year assessment of SAILER for Ford and the Institute of International Education (IIE). Logistically, the IIE housed the money Ford issued for SAILER. Created in 1919, the IIE had earned a strong reputation as an efficient administrator for non-profit programs that wished to work abroad; ${ }^{108}$ for this reason Ford opted to outsource the day-to-day financial operations of SAILER to the IIE. There was a two-pronged approach that SAILER employed during this initial period. For certain countries, there was what one respondent referred to as an experi-

\footnotetext{
${ }^{107}$ Bainbridge, THE SAILER PROJECT, supra note 9, at 29-32.

${ }^{108}$ For background on the IIE, see INSTITUTE OF INTERNATIONAL EDUCATION; http:// www.iie.org (last visited Nov. 18, 2011).
} 
mental, "testing the waters with your toes"109 strategy. For other countries, there was a deeper, more sustained, and fuller-fledged commitment, with respect to dollars spent and staff sent. ${ }^{110}$

In terms of the former, those countries included: Congo, Kenya, Lesotho, Malawi, and Zambia. The reasons for moving more cautiously varied depending upon the setting. For example, in Kenya, legal education during the 1960s underwent major changes. The University of Nairobi-Faculty of Law only opened in 1970. Prior to that, from 1963-1970, interested students studied at the Kenya School of Law, which was a five year program that combined two years of academic courses with three years of articling. ${ }^{111}$ However, before 1963, for students seeking a career at the bar, training mainly occurred in Britain. ${ }^{112}$ The other higher educational center was the Kenya Institute of Administration (KIA). KIA was established in 1961, and while geared towards training civil servants, it offered a series of law courses, for which SAILER initially supported one instructor, Philip Durand, in 1967.113

In Congo, there was internal conflict and great "student unrest,"114 which dampened hope for in-depth SAILER involvement. In addition, competition existed between the country's two main educational institutions - a school of civil service, the Ecole Nationale de Droit d'Administration, which already was receiving non-SAILER financing by Ford, and Lovanium University, which sought to build a law faculty of its own. With the lingua franca not being English, combined with the low number of students who pursued law at the latter, ${ }^{115}$ SAILER decided to fund only one teaching line to test whether remaining involved in Congo made sense.

109 Interview with SAILER-participant (Aug. 24, 2010) (anonymity provided upon request).

$110 / d$.

111 See BAINBRIDGE, supra note 11, at 236-43. Note the coursework took place in the first and fifth years. Id. at 242 .

112 Id. at 242.

${ }^{113} / d$. at 239-41. For an in-depth examination of the politics of the Kenyan bar, particularly as it related to the nation-building and constitutional design-making process, and its interactions with U.S. Supreme Court Justice Thurgood Marshall, see Mary Dudziak, Exporting American Dreams: Thurgood Marshall's African Journal (2008).

${ }^{114}$ See Bainbridge, THE SAILER PROJECT, supra note 9, at 61.

115 Even by 1966, there were 2200 students at the university, but only 30 sought to obtain a law degree. $I d$. 
Likewise, in Malawi, there was simply a dearth of Malawian law students and lawyers. ${ }^{116}$ The three teachers funded by SAILER helped develop law reports, teaching materials, and broad legal education strategies for the Malawian government. But the infrastructure and logistics did not make it efficient, in Ford's eyes, to commit further resources to the country.

A similar assessment explained Bainbridge's decision to only minimally support Lesotho. ${ }^{117}$ Enclosed within southern Africa-within what is today the modern state of South Africa-Lesotho was steeped in the tradition of Roman Dutch law. ${ }^{118}$ Its main university (the University of Botswana, Lesotho, and Swaziland) served as a safe haven and intellectual sanctuary for scholars, students, and interested foreigners to oppose apartheid practices. ${ }^{119}$ Yet because of its poor economy, weak infrastructure, and Ford's perception that it had little power or influence within Africa, Lesotho received funding from SAILER for only two academics and little subsequent support thereafter. ${ }^{120}$

And in Lusaka, while there was an affirmative decision by the University of Zambia to adopt the American law school method, ${ }^{121}$ including requiring Zambian law students first to have undergraduate degrees, ${ }^{122}$ revamping the system would take several years to manifest. Therefore, SAILER funded only two teachers to assist initially: Cliff Thompson, who had worked in Sudan and Thomas Lamia, who had spent time at the University of Ife in Nigeria. ${ }^{123}$

\footnotetext{
${ }^{116} / d$. at 78 (noting: "[a]t the time of independence there was but one Malawi lawyer".).

$117 / d$, at $72-73$

$118 / d$. at 73 .

119 To highlight this point, see Alistair Boddy-Evans, Desmond Mpilo Tutu, ABOUT.COM GUIDE, AFRICAN HISTORY, http://africanhistory.about.com/od/peopl1/a/ Desmond-Tutu-Biography.htmhttp://africanhistory.about.com/od/peopl1/ a/Desmond-Tutu-Biography.htm (last visited Nov. 18, 2011) (noting that "[i]n 1969 [Desmond] Tutu took a teaching post with the University of Botswana, Lesotho and Swaziland (UBLS) ... [ which was] slightly insulated from the worst of Apartheid's excesses....").

${ }^{120}$ See Bainbridge, THE SAILER PROJECT, supra note 9, at 72-73.

${ }^{121}$ Namely, in that this would be "a graduate discipline." /d. at 97.

122 /d. This was the plan of the Dean, Kwamena Bentsi-Enchill, a Ghanaian who was Oxford, Chicago, and Harvard educated, and someone whose plans Bainbridge saw as "visionary": Id.

${ }^{123}$ Id.
} 
For Ethiopia, Ghana, Liberia, Nigeria, Sudan, and Tanzania, where SAILER committed comparatively more resources, the decision to enter these countries also was made on a case-by-case basis. In the next section, there will be specific focus on what occurred in Ethiopia, Ghana, and Nigeria. But two underlying reasons existed for why SAILER dedicated finances and personnel to all of these six states. First, the political and legal leadership in each, at least initially, invited, accepted, and even embraced the educational aspirations of SAILER. The episode involving James Paul and the Ethiopian Emperor, Haile Selassie, although perhaps most supportive of this point, reflects a general attitude also exhibited by the Ghanaian, Liberian, Nigerian, Sudanese, and Tanzanian leadership as well. Of course, an instrumental and even cynical explanation for these leaders' interest in SAILER may be that there was the sheer desire to have foreign aid from the United States. After all, if these governments could avoid spending on legal education, then they could use this money for other purposes. But this rationale is too simple and ignores the fact that there was both an interest and perceived need in having strong legal professionals emerge within these countries to spur serious economic, legal, and political development. The other reason for why the SAILER-team opted to participate heavily in these selected countries was because it was assured that its assistance in research-development would be welcomed, and that the different governments saw rigorous research as vital for improving their respective legal systems.

So, for example, beginning in 1960 , Ford provided funding for what became known as the Sudan Law Project. ${ }^{124}$ The main goal was for the law faculty at the University of Khartoum to document and categorize all case law and legal papers from Sudan before the country gained independence from Britain in 1956. ${ }^{125}$ In 1963, SAILER took over the direction of this project and the teachers it funded worked extensively on this compilation. ${ }^{126}$.The SAILER teach-

${ }^{124}$ For general insights, see William L. Twining, Sudan: Legal Studies at the University of Khartoum, J. AFr. STUD. 145 (1962).

125 Id.; see also Bainbridge, THE SAILER PROJECT, supra note 9, at 89 . Also, Jeswald Salacuse was heavily involved in this project as well. See Twenty Years After, A Conference of Law Teachers Who Worked in Africa 65 (Sept. 26-27, 1986) (papers from proceedings compiled by John $\mathrm{S}$. Bainbridge, on file with author).

126 See Bainbridge, THE SAILER PROJECT, supra note 9, at 89. 
ers also labored on the Sudan Law. Journal and Reports, which organized judicial rulings following independence. ${ }^{127}$. In Tanzania, the SAILER-leadership saw great research potential at the University of East Africa's law faculty at Dar-es-Salaam. Not only was there an intense desire on the part of the Dar administration to improve the law library, which impressed Bainbridge and others, but the faculty itself was a cosmopolitan, global mix. By 1966, there were " 8 British expatriates (including the Dean, an Australian), 7 Africans (including East Indians in origin though born in East Africa), the 2 SAILER teachers, and 3 other Americans." ${ }^{128}$ Among this group was a young stellar intellectual, Yash Ghai, who would later rise to dean and proceed to become one of the most famous comparative law scholars of the twentieth century. ${ }^{129}$ And in Liberia, at the Louis Arthur Grimes School of Law, SAILER was encouraged to devise major legal education reforms. Admissions standards were raised, the curriculum was. academically strengthened; the law library was enhanced, SAILERparticipants prepared teaching materials, and the Liberian Law Journal saw its inaugural issue published in $1965 .^{130}$

In spite of the initial political support of SAILER from these African leaders, problems nevertheless emerged. In Sudan, for instance, tension arose as to what role English or Arabic should play in legal discourse. As Bainbridge and his colleagues discovered, certain Sudanese political leaders insisted on Arabic being used and Islam

${ }^{127} / d$. A third research project in which the SAILER teachers participated was the Sudan Law Reports, which essentially was the compilation of law judgments (taken from the Sudan Law Project) prior to independence. Id. See also supra note on Salacuse accompanying note 125 .

128 Bainbridge, THE SAILER PROJECT, supra note 9 , at 95 . Enthusiasm was present too because American Fulbright scholars were keen on working with SAILER in Tanzania. Id.

${ }^{129} / d$. at 96 . For a further discussion, see infra notes 314-15. Moreover, for a present-day example of a University of Dar-es-Salaam graduate representing a global scholarly outlook, see the work of Dean Makau W. Mutua, who earned his LL.B. and LL.M. from Dar and then proceeded to matriculate from Harvard Law. School with a LL.M. and S.J.D. (He also studied at the University of Nairobi.) For background on Dean Mutua, see Makau W. Mutua Bio, University at Buffalo LaW ScHOOL, http://law.buffalo.edu/Faculty_And_Staff/dynamic_general_profile.asp? faculty=mutua_makau (last visited Nov. 18, 2011); and for a sample of his international and comparative law work, see MaKaU MUTUA, HuMAN RIGHTS AND NGO's IN East Africa: Political and Normative Tensions (2008); Makau Mutua, Kenya's Quest for Democracy: Taming Leviathan (2008).

130 See Bainbridge, THE SAILER PROJECT, supra note 9, at 74-77. 
being incorporated into the legal curriculum. ${ }^{131}$ By 1966, the University of Khartoum introduced a new three year graduate law program (moving away from its previous five year program), requiring students now to have completed two years of liberal arts education before pursuing their legal studies. ${ }^{132}$ Within this new program, however, there existed an option whereby students could complete an LL.B. in civil law or, alternatively, one in Sharia law. ${ }^{133}$ The government also established a rival institution, the Omdurman Islamic University and supported another, the University of Cairo-Khartoum Branch. ${ }^{134}$ Both these universities emphasized religious law and conducted classes in Arabic, but perhaps more importantly they displayed the seriousness under which the government wished to offer an alternative to secular higher education. Hostility between the United States and Sudan increased during the mid-1960s. Eventually, the American government broke off diplomatic ties with Khartoum in July of 1967, all but ending SAILER's operations within the country. ${ }^{135}$

In Tanzania, the main tensions were internal faculty politics between the Dean, A.B. Weston, and the Principal of the University College, R.C. Pratt. ${ }^{136}$ Discord also existed between the law faculty and the bench and bar, with judges and lawyers believing that the

\footnotetext{
${ }^{131} / d$. at 89-94. See also Twining, supra note 124.

132 Bainbridge, THE SAILER PROJECT, supra note 9, at 90-91.

${ }^{133}$ In fact, the LL.B. in Sharia law was to be four years. See BAINBRIDGE, supra note 11, at 311-12.

${ }^{134}$ Bainbridge, THE SAILER PROJECT, supra note 9, at 91-93.

${ }^{135}$ Id. at 93-94. The SAILER teachers who were expecting to return for that fall semester had difficulty revalidating their passports from the U.S. State Department. Eventually, two of the three SAILER teachers were able to do so, but they returned to a university that was hostile to them, with a Dean (Zaki Mustafa) who had proceeded to hire replacements. (The documents also suggest that Dean Mustafa had grown increasingly resistant to the SAILER methods of legal education. While he and Bainbridge remained "most friendly," id. at 94, the Dean faced political pressure as well as the reality that many of the Khartoum law students simply had intense difficulty succeeding under the American legal education model for various reasons. According to Mustafa, the students were not proficient in English; they had been trained under a rote memorization method; and their pre-law school educational experiences overall were fair to moderate at best. $l d$. at 92 94).

${ }^{136} / d$. at 95 (noting that by "1965 Dr. Pratt was succeeded by the registrar of the university, Dr. Wilbert Chagula, who apparently has proven to be a very able administrator and principal of the University College.").
} 
academics had become too insular from the practice of law. ${ }^{137}$ And in Liberia an admixture of political and university troubles contributed to a slowing of otherwise positive developments in the legal education sphere there. ${ }^{138}$

In the next section, there will be a more detailed focus on three of the other countries in which SAILER greatly invested: Ethiopia, Ghana, and Nigeria. In addition to the archival documents from Ford, the author's fieldwork in these three settings sheds light on what motivated the SAILER-leadership's interest and how its legal education initiatives unfolded.

\section{THE SAILER EXPERIMENT IN DETAIL: A LOOK AT THREE DIFFERENT COUNTRIES}

\section{A. The Case of Ethiopia}

\section{The Deanship of James Paul}

As home to one of the early cradles of human civilization, Ethiopia's complex, fascinating, distinct, and at times, tragic history has been detailed for generations by various scholars. ${ }^{139}$ Discussing the intricate political, cultural, and socio-economic evolution of Ethiopia goes beyond the scope of this study. But in terms of modern legal education, relevant here is that when SAILER began its project in the early 1960 s, Ethiopian law was a mix of customary traditions, religious norms, feudal regulations, imported continental

137 id. at 96. In large part, according to Bainbridge, this likely was the result of the law faculty's location being moved outside of Dar to a place called University Hill.

138 The positives included improvements in the law library, faculty seminars, a publication of a law journal, and rigorous training of judicial magistrates. Id. at 7677. However, according to Bainbridge, the problems were: a lackluster student body, poor infrastructure, a lack of interest among Liberians to pursue legal academia, and a very low salary cap on all government officials, including on university teachers, which contributed to a low interest in government work, especially in terms of working in public law. Id. at 74-76.

${ }^{139}$ See e.g., Herbert Lewis, The Development of Oromo Political Consciousness, 1958-1994, in BeIng ANd BeComing Oromo 37-47 (eds., P. Baxter et al. 1996); HeRBERT LeWIS, Jimma AbBa Jifar: AN Oromo Monarchy, EthIOPIA 1830-1932 (2001); HaRold G. MARCUS, A History of ETHIOPIA (2002); RichaRd PANKHURST, ThE ETHIOPIANS: A HISTORY (2001). For a key piece on the legal pluralism of the day in Ethiopia, see Norman J. Singer, A Traditional Legal Institution in a Modern Legal Setting: The Atbia Dagnia of Ethiopia, 18 UCLA L. Rev. 308 (1970-71). 
codes, and Anglo-American civil and criminal procedural rules. ${ }^{140}$ The Emperor during this time was Haile Selassie I, who had come to power in $1916 .{ }^{141} \mathrm{An}$ almost mythical-like figure to some in stature and presence, Haile Selassie was born into an Orthodox Christian family with roots going back several centuries. ${ }^{142} \mathrm{He}$ also served as the inspirational savior for those adhering to the Rastafari movement, and, internationally, he was viewed by many as cosmopolitan, particularly following a speech at the League of Nations in 1936 where he advocated for a collective response to the use of force against the Ethiopian people by the Italian military that was present in Africa. ${ }^{143}$

For the leaders of SAILER, and in particular James Paul who had traveled to the country "several times,"144 Ethiopia served as the land of the possible in terms of legal education reform. Despite Haile Selassie's drawbacks, he was a leader that appeared to embrace modernizing the country's legal system. ${ }^{145}$ In addition, the government welcomed foreign-specifically American-law professors to embark on the creation of a new law school that it claimed would produce the next generation of not just legal, but political, societal, and nation-building leaders as well. The Ethiopians and Americans saw the country as an opportunity where law could be used as an instrument that might close what Roscoe Pound famously saw as the chasm between "law-in-books and law in

${ }^{140}$ See Paul, supra note 54, at 24. See also Bainbridge, THE SAILER PROJECT, supra note 9, at 65 (noting at the time how "the penal law is based on Swiss sources with reference to Yugoslav, Greek and Brazilian sources, the civil and commercial codes are based on French and German sources, the code of criminal procedure draws on the Indian code while the constitution of Ethiopia and its public law draw on Anglo-American sources. Added to this is a strong reference to religious law as outlined in the Fetha Negast promulgated in the 13th century."). See also Peter H. Sand, Book Review: Heinrich Scholler, Recht und Politik in Athiopien: Von der traditionellen Monarchie zum modernen Staat, 57 AM. J. COMP. L. 754 (2009).

${ }^{141}$ See generally Harold G. Marcus, Halle Selaisse: The Formative Years 1892-1936 (1986).

$142 / d$.

$143 / d$. For a text of the speech, see Appeal to the League of Nations: Haile Selassie (June 1936) http://www.mtholyoke.edu/acad/intrel/selassie.htm (last visited Nov. 18, 2011).

144 See Paul supra note 54, at 24.

$145 / d$. 
action." ${ }^{146}$ For these reasons then, the fit between SAILER's vision and Haile Selassie's objectives seemed a compatible match.

In September of 1963, the faculty of law at the imperially named university opened, with James Paul inducted as the first dean. (Note that about a decade earlier, efforts to launch a Franco-phone law school in Addis failed to materialize. ${ }^{147}$ ) An internal SAILER memo reveals how enormous a challenge existed for Paul and his inaugural faculty. Simply put, "there was no law library, no law books, no reports, not the most elemental tool of the lawyers' craft."148 For this reason, Paul and his colleagues had to start by placing pen-to-paper and publishing casebooks, law reviews, statutory supplements, and other academic and legal texts. ${ }^{149}$

As daunting as these tasks were, there was also the day-to-day administration of the LL.B. program. From the outset, the Paul administration decided that there would be two methods of enrollment for the law degree. One would be where students could pursue their studies on a full-time basis and earn a diploma in three years; the other would be "a four year night program"150 that would cater to those who had already earned a bachelor's degree and who were working in the government civil service. In 1963, a total of sixty-one students were enrolled in both programs, and in 1964 another separate continuing legal education-type program was added, with some four hundred already practicing lawyers and judges participating. 151

Furthermore, Paul insisted on ensuring that his law teachers were "assigned to one course only. . . ."152 There was a dual purpose for enacting this norm early-on. The first was so that research and writing could be encouraged to flourish. ${ }^{153}$ Indeed, in that first year, the law faculty produced a project that involved compiling a great

\footnotetext{
146 This idea draws on specifically Paul's observation, id. at 24, where he remarks, given this Poundian situation, that "Ethiopia was a classic example."

${ }^{147}$ Bainbridge, The SAILER PROJECT, supra note 9, at 65.

148 Id.

$149 / d$.

$150 / d$.

${ }_{151} / d$. Participants in the latter earned a certificate upon completion.

152 Id. at 66.

$153 / d$.
} 
amount of material on the land tenure situation in Ethiopia. ${ }^{154}$ Also during Paul's tenure as dean (1963-1967), the Journal of Ethiopian Law became a regular publication, and a fully-operational law library-with some 10,000 volumes-emerged at the law school. ${ }^{155}$ But the second reason was so that the law faculty could have time to interact and build relationships with members from other academic units on campus. ${ }^{156}$

Nevertheless, issues still existed-serious ones at that. Paul wrote detailed letters back to colleagues in the United States insisting that he needed more funding to continue to implement his initiatives. One letter, from March 1964, was written to Harvard Law's Joseph Leininger, who was then the school's Secretary of International Legal Studies. In it, Paul expressed his disappointment after learning that Harvard would not fund one of its recent law graduates, Harrison Dunning, to teach at Haile Selassie University. ${ }^{157}$ Because of Dunning's previous work in Kenya on land law, and the fact that Ethiopia had adopted a Civil Code that was to "displace a considerable body of traditional [land] law"158 of its own, Paul considered it key to "having a man of Mr. Dunning's caliber associated with" 159 his faculty. Paul had solicited Harvard mainly because of the frustration he encountered with SAILER administrators regarding the delay in delivering funding to the law school. ${ }^{160}$

$154 / d$.

155 Id. at 67-68 (referring to it imprecisely as the Ethiopian Law Journal). Peter $H$. Sand has comprehensively compiled what he has titled a "Bibliography of Publications by Former Foreign Faculty Members and Visiting Lecturers, Addis Ababa University Faculty of Law." The entries include many citations to articles published in the Journal of Ethiopian Law (sent by Sand to author; on file with author.)

${ }^{156}$ Here a number of activities occurred. For example, the university initiated a lecture series and mentoring program for students on their research and writing skills. Id. at 66-67. In addition, in the fall of 1964 a new initiative (in English) was launched and directed towards "government officials, prosecutors, judges, members of parliament and advocates." Id. at 66. Note, this program was in total three years and provided graduates with an actual diploma. Another track of studies was offered as well, in criminal law, criminal procedure, and military law to a similar set of constituents who lived in the city of Asmara, and this was two-and-one half year program. Id.

${ }^{157}$ Letter from James C.N. Paul to Joseph E. Leininger (Mar. 25, 1964) (on file with author).

158 James C.N. Paul, Reference Letter for Harrison Dunning 1 (Mar. 25, 1964).

159 Id. at 2.

${ }^{160}$ Indeed, in the letter to Leininger, it appears that Paul sent a copy to Frank Sutton as well. (Although, officially Sutton was not copied on the letter). The reason it 
In April of 1964, Paul wrote to Ford arguing that if the Haile Selassie law faculty were to succeed, the support from Ford needed to be quickened and enhanced, especially for faculty hires. ${ }^{161}$ There had to be additional resources devoted towards the library, towards producing more casebooks, and towards developing pedagogical tools to assist new instructors on how to teach. ${ }^{162}$ And Paul insisted that there be greater "Ethiopianization"163 of the faculty, urging the SAILER-administrators to invest more heavily in training local Ethiopians to enter into the academy.

These pressures weighed heavy on Paul, to the point where he remarked that he could not "rest easy till we get this [set of financial matters] out of the way-because these are commitments already made and vitally relevant." 164 In fact, Paul's unease was so manifest that he wrote a follow-up correspondence to Francis Sutton in New York reiterating his worry about the "red-ink position" 165 of the law school and the strong likelihood that the institution would be have to incur "deficit-financing." ${ }^{166}$ Paul's anxiousness over the lack of necessary funding continued into the following year. In March of 1965 he made an "urgent plea"167 to Sutton to increase funding for the Ethiopian law school. He even privately confessed to Sutton how he had become "tired ... [and] discouraged" with the entire endeavor. ${ }^{168}$

appears so, is because on the copy the author has, which came from the Ford Foundation, where Sutton worked, there is a hand-written note from Paul that reads: "Dear Frank: When are you coming []? [bracketed word illegible]. And what on earth is happening in New York to SAILER's application?!! We look forward to seeing you. Jim."

161 See Letter from James C.N. Paul to Francis X. Sutton and Courtney A. Nelson (Apr. 13, 1964) (on file with author) (bemoaning the fact that because of a lack of funding Paul could not retain the services of Kenneth Redden, who would later go on to be a prominent professor at the University of Virginia).

162 Id. In this memo, Paul also reiterates his hope for financial support for Harrison Dunning.

$163 / d$.

164 Id.

165 See Letter from James C.N. Paul to Francis X. Sutton (Apr. 17, 1964) (on file with author).

$166 / d$.

167 See Letter from James C.N. Paul to Francis Sutton (Mar. 10, 1965) (on file with author).

${ }^{168} / d$. (although as he quickly added, as if to comfort Sutton: "I assure you I have never had more zest for a project, nor more stimulation, nor more hope that I am 
Eventually, the funding for which Paul worked relentlessly arrived. In April 1965, Ford approved a new, nearly one million dollar, threeyear grant. ${ }^{159}$ For the next eighteen months Paul continued attempting to strengthen the quality of education and diversify the faculty, although through the calendar year, 1966, the teachers remained predominantly Western-based. Along with the nine SAILER-supported American teachers, Paul also had the occasional teacher funded by the United States Peace Corps, plus there were faculty members from Britain, West Germany, Belgium, and Poland. ${ }^{170}$ Still, Paul aspired for the eventual "Ethiopianization of [the] faculty," ${ }^{171}$ even though he worried that this may be "a long way off." 172

By 1967 university officials and the government asked Paul to assume the role of Vice President of Academic Affairs for the entire institution, which he accepted. Paul's resilience impressed his superiors. Although the law faculty by 1967 no longer offered a parttime, four year LL.B. program, the three year program remained and was thriving, as were other short-term courses for government officials and working professionals. ${ }^{173}$ But what would become of

engaged, with other fine people, in a task which may truly yield tangible fruit in the course of time.").

${ }^{169}$ The archival documents are unclear as to how much money specifically was allocated to Ethiopia. The official grant application, File \#62-293 (Apr. 12, 1965), notes that a three year grant of $\$ 991,000$ was approved, and the accompanying letter by Ford to Mr. Kenneth Holland, President of the Institute of International Education (the body administering the grant) confirms the same. However nowhere in the grant application or in the letter to Holland is Ethiopia mentioned as the sole beneficiary. At the same time, in a letter dated April 15, 1965 from Francis Sutton to James Paul, the former notes that Ford "has now approved a grant of slightly over $\$ 1,000,000$ to continue the SAILER program and it is my understanding that appointment under that program will be available to you in Addis Ababa." The principle actors with whom the author spoke (Sutton and Paul) did not have recollection on the specific amount devoted to the Halie Selassie University. Note also that in March of 1965, Sutton received a correspondence from his deputy, Courtney Nelson, who was the liaison between New York and East Africa. In it, Nelson extols the progress Paul has made and resoundingly affirms his belief that support from Ford should continue. See Courtney A. Nelson Memo to Francis X. Sutton (Mar. 19, 1965) (on file with author).

170 See Ford Foundation Memo on the University of Haile Selassie I, Law School, Addis Ababa 11 (Jan. 27-29, 1966) (on file with author).

${ }^{171} / d$.

$172 / d$.

173 Memorandum, Faculty of Law, Haile Selassie I University, Addis Ababa, Ethiopia 2 (Feb. 4, 1964) (on file with author). 
the law faculty with his departure? The next section examines the Haile Selaisse law school in the years following Paul's deanship.

\section{The Post-Paul Era}

By 1967, the Addis law school was becoming a vibrant place of learning. ${ }^{174}$ Thus with James Paul's shift into university administration, the institution needed a new able dean. SAILER officials in New York recruited Yale Law School Professor Quintin Johnstone to fill this role. ${ }^{175}$ Johnstone was previously based in Tanzania and had a good relationship with SAILER director, John Bainbridge. However, succeeding Paul was a difficult task and Johnstone was keenly aware of the challenges he faced. ${ }^{176}$ Yet Johnstone's approach for how to run the law school was embraced not just by his American overseers but by the Ethiopians with whom he interacted. The reason was simple: Johnstone also advocated strongly for fully turning over legal education to the Ethiopians. ${ }^{177}$ Some months before his appointment, Johnstone delivered a lecture at a SAILER-held symposium in New York where he expressed concern that African law schools had engaged in "too much mimicry as to what $\therefore$. [was] done in England and the United States."

For Johnstone, the curriculum had to focus on training lawyers who could be efficient government officials as well as those who

\footnotetext{
${ }^{174}$ Bainbridge, THE SAILER PROJECT, supra note 9, at 68 (note, Tuori finds that "by 1967 [there were] close to 700 students in its various program in English and Ahmaric."). See Kauis Tuori, Legal Pluralism and Modernization: American Law Professors in Ethiopia and the Downfall of the Restatements of Customary Law, J. LEGAL PLURALISM at 10-11 (forthcoming).

175 Bainbridge, THE SAILER PROJECT, supra note 9, at 68.

176 Interview with Quintin Johnstone (Mar. 18, 2011).

$177 / d$. See also interview with a current member of the Addis law faculty (who were SAILER students and who vividly recalled Johnstone's deanship approach) (Aug. 6, 2010); interviews with members of the Addis Ababa Law Alumni Association (Aug. 7, 2010).

178 Symposium on the Special Curricular Needs and Problems of Law Faculties in Anglophonic Africa, Memo on the Project on the Staffing of African Institutions of Legal Education and Research, The Institute of International Education (Sept. 9, 1966) (on file with author.) Note also, Kaius Tuori has written an important paper that discusses how Professor Arthur Schiller (the founder of the African Law Center at Columbia) devoted great effort at trying to revitalize rigorous study of indigenous law in Ethiopia: As Tuori explains, Schiller's efforts occurred and coincided with the law-and-development efforts like that of SAILER's. For a detailed discussion of Schiller's work in this area, see Tuori, supra note 174.
} 
were fluent in local criminal and family law matters. ${ }^{179} \mathrm{He}$ also believed African legal education needed to address the fundamental issues concerning state governance, such as "agricultural development, urban land use and development, government organization and administration and public health." ${ }^{180}$ And he argued that the law faculty had to be centrally involved in: continuing legal education for practitioners, a vast array of law reform and empirical legal studies projects, legal aid clinics that could be "relevant to the masses," 181 and efforts to train students to be solid researchers. ${ }^{182}$ Johnstone did not believe that foreign expatriates could impart these goals independently and without local assistance. To that end, he made it his primary objective to bring onto the permanent faculty Ethiopians who could lead these initiatives. ${ }^{183}$

This plan was continued by Johnstone's successor, Cliff Thompson, who had been in Zambia and Sudan on SAILER-related projects before coming to Addis to assume the deanship in 1969. Thompson also previously served as Associate Director for Columbia Law School's African Law Center (ALC) where one of that institute's major goals was to promote African legal studies among American scholars. ${ }^{184}$ As part of this process, the ALC published the African Law Digest, which was the flagship journal in the United States for legal scholars interested in law-related developments in Africa. ${ }^{185}$

${ }^{179}$ See Symposium on the Special Curricular Needs, supra note 178 . See also interview with Quintin Johnstone (Mar. 18, 2011).

${ }^{180}$ See Symposium on the Special Curricular Needs, supra note 178 , at 5.

181 /d.

182 Id. at 5-6.

${ }^{183}$ Interview with Quintin Johnstone (Mar. 18, 2011); Johnstone's goal was to hire three Ethiopians a year. While he fell short of this goal, by the time he left in 1969, a total of three Ethiopians were on staff. Also note that as of October 16, 1967 , the period in which Johnstone began his tenure, the following people were SAILER teachers at Haile Selassie I University Law: Richard Cummings, Harrison Dunning, William Ewing, Stanley Fisher, Quintin Johnstone, Michael Kindred, Laurence Knowles, John B. Marshall, Paul McCarthy, Norman Singer, and Peter Strauss. See Ford Foundation Memorandum, Current SAILER Teachers (Oct. 16, 1967) (on file with author).

${ }^{184}$ See Letter from Cliff Thompson to John Bainbridge (Feb. 8, 1966) (describing the African Law Center) (on file with author).

${ }^{185}$ Id. As noted, the ALC was founded by Professor Arthur Schiller. Along with the African Law Digest, the ALC published the African Law Studies. In the late 1960 s, Professor Richard Abel assumed the editorial functions of the ALS; it even- 
Thompson served as the third dean of the Haile Selassie law faculty from 1969-1973. During that time legal life on campus was intellectually exciting but there were external political events that posed challenges to those living in the capital city. ${ }^{186}$ In the early 1970s, protests against the Emperor occurred. There were shootings on campus by the Emperor's security officials; at one point, the student class president was murdered with his body subsequently stolen from the burial site. Marxism and anti-Americanism (particularly regarding the United States' presence in Vietnam) were ideological forces that mobilized many of the young. And as former SAILER students stated, there was suspicion among some Ethiopians at the university that the American law teachers were tied to the ClA. ${ }^{187}$.

But most interestingly, in spite of these dangerous developments, inside the law school the legal training of the SAILER students continued. Funding from Ford remained. Matriculation rates steadily rose as did the Ethiopianization of the law faculty. In fact, by the time Thompson departed for a new teaching post at Southern Methodist University in 1973, twelve of the twenty-one teachers on staff were Ethiopians. ${ }^{188}$ As one now-prominent Ethiopian lawyer and student during the Thompson years articulated, for him and his fellow students being part of SAILER was "emotionally schizophrenic." 189 "While the outside world appeared to be tearing apart at the seams - and while there was some ideological attraction to opposing the Emperor-being in law school served as a refuge from the chaos. The educational confines provided academic stimulation,

tually evolved into the Journal of Legal Pluralism. Author correspondence, Professor Richard Abel, Aug. 16, 2011. For further background on Schiller, see Tuori, supra note 174.

186 Interviews with Cliff Thompson (Mar, 15, 2011 and Aug. 25, 2010). See also interviews with current members of the Addis law faculty (Aug. 6, 2010); interviews with members of the Addis Ababa Law Alumni Association (Aug. 7, 2010).

${ }^{187}$ The description of these events comes from interviews conducted with current members of the Addis law faculty, August 6, 2010, and with members of the Addis Ababa Law Alumni Association, during a general meeting of this body that took place on August 7, 2010. (Indeed, even James Paul conceded that he heardmuch to his bewilderment - that some of the students saw him and his colleagues as operatives of the American government. Author interview, Dec. 14, 2010).

188 Interview with Cliff Thompson (Mar. 15, 2011).

189 Interview with lawyer (Aug. 7, 2010) (who asked to remain anonymous) 
creativity, and as this lawyer stated, "hope"190 that law could be used as a means of bringing rationality, opportunity, and equality to the vast majority of Ethiopians who had been deprived of so much for so long.

Shortly after Thompson's departure, Paul left as well, and eventually, by 1975 , the SAILER initiative in Ethiopia ended. That same year and in the years subsequent, the country was engulfed in violent political turmoil that resulted in the overthrow of Haile Selassie. ${ }^{191}$ The brutal military regime known as the Derg soon came to power and oversaw a reign of terror that lasted until $1987 .{ }^{192}$ The political climate obviously did not auger well for aspirants of rigorous, independent legal education and there was little ambition from abroad to devote further resources for such a venture. As will be seen next, macro-political factors affected the Ford Foundation's decision-making processes in two other African countries as well.

\section{B. The Case of Ghana}

As described in Sections I and II, Ford's involvement with Ghana dated back to the late 1950s. The 1962 conference on legal education in Accra highlighted Ford's commitment to Ghana and its desire to work with those who sought foreign assistance to improve the status of the country's legal profession. One fact that the Ghanaians and Americans recognized was how few solicitors existed. One report even cited that as late as 1964-seven years after Ghana declared independence from Britain-only a dozen or so solicitors were present in the entire country. ${ }^{193}$ Remember also that there was a bifurcation of legal education in Ghana. At the University of GhanaLegon, which opened in 1959, law was taught as an undergraduate degree in the Department of Law at the University College. From there, professional/practical training occurred at the Ghana Law School. ${ }^{194}$ Initially, the Briton, Professor J.H.A. Lang, headed both in-

\footnotetext{
$190 / d$.

${ }^{191}$ Scholars studying this period note that the Selassie regime engaged in corruption, authoritarianism, and widespread suppression of political opponents. See generally MARCUS, supra note 139; PANKHURST, supra note 139.

192 See e.g., MARCUS, supra note 139; PANKHURST, supra note 139.

${ }^{193}$ See William B. Harvey, The Development of Legal Education in Ghana, an internal report, as cited in BAINBRIDGE, supra note 11, at 18.

${ }^{194}$ Note the latter technically came into existence one year prior to the former.
} 
stitutions, but by 1962 he resigned after clashing with President Kwame Nkrumah.

Nevertheless, SAILER-officials remained hopeful and even invited President Nkrumah to deliver the keynote address before the 1962 Legon conference. Nkrumah's stated priorities for Ghanaian legal education seemed to intersect with the perspectives of people like John Bainbridge, James Paul and the other American delegates. ${ }^{195}$ For example, Nkrumah noted that in the Ghanaian context law had to be used for enhancing socioeconomic opportunities. ${ }^{196}$ Legal education also had to import the best practices from the West but then adapt them to the needs of future Ghanaian lawyers, including ensuring that Ghanaian law students were trained in local customary law. ${ }^{197}$

In spite of the skepticism expressed by earlier Ford consultants such as A.N. Allott, and Ford's private concerns that Nkrumah was not the pluralist that he promoted himself to be, by 1963 the SAILER-leadership opted to provide "the most substantial assistance to a single institution [University of Ghana] under the program"198 to date. To replace Lang in leading the law faculty at the university, prominent Michigan Law Professor W. Burnett Harvey was persuaded to assume the role of dean-a major coup for Bainbridge and his SAILER-team. ${ }^{199}$

Harvey, a Navy veteran from the Second World War, became a faculty member at Michigan, his law school alma mater, in 1951. A legal philosopher and contracts scholar, Harvey also studied comparative law and had a keen interest in post-colonial Africa. ${ }^{200}$ After

195 Nkrumah's speech was reprinted as: Kwame Nkrumah, Ghana: Law in Africa, 6 J. AFR. L. 103 (1962).

$196 / d$.

197 ld.

198 Ford Memorandum, Request for Grant Action, Request No. OD-1257G 2 (June 3,1963 ) (on file with author).

${ }^{199}$ See id.; see also Ford Memorandum, Request for Grant Action, Request No. OD-998G 3 (Apr. 27, 1962) (on file with author).

200 This information comes from a webpage dedicated to Harvey on the University of Michigan Law website, see William B. Harvey Bio, Michigan Law, http://www. law.umich.edu/historyandtraditions/faculty/Faculty_Lists/Alpha_Faculty/Pages/W illiamBHarvey.aspx (last visited Nov: 18, 2011). For a tribute to Harvey's career, see In Memoriam: Celebration of the Life of William Burnett Harvey, 80 B.U. L. REv. 692 (2000) (tributes by Ronald A. Cass, John Silber, and Todd Klipp). 
his deanship at Legon, Harvey would go on to write a book on "law and social change in Ghana," 201 and his interest in the region would continue throughout the rest of his academic career, including while dean at Indiana University-Bloomington and later as a professor at Boston University. His tenure at the University of Ghana, while short, would prove to be of great importance for the SAILER program.

Upon his arrival in Accra, Harvey made it a point to pursue a faculty hiring strategy similar to the one espoused by his colleagues in Ethiopia. Namely, Harvey strongly believed that a Ghanaian presence was required in order to establish legitimacy among the students, his domestic audiences, and the international community. He adamantly did not want even an appearance that he was leading a new group of foreigners to impart legal wisdom from abroad. While this may have been somewhat inevitable, he soon had many Ghanaians affiliated with the faculty. By the fall of 1963, there were nine Ghanaians who taught in either a full or part-time capacity, including S.K.B. Asante, who would become one of the country's most famous academics and lawyers in the twentieth century. ${ }^{202}$

Beyond diversifying the faculty, Harvey's main stamp on the institution came in the way of transforming the manner in which students could enter the legal profession. Prior to his arrival, the University of Ghana awarded a four-year LL.B. degree, which was then followed by a one-year professional tutelage at the Ghana Law School. However, through consultation and negotiations with government officials and members of the bar, Harvey gained consensus to move all legal education training under the auspices of the university. Students, thereafter, would first earn "a three-year, nonprofessional law degree, to be called the Bachelor of Arts (Honours) in Law, and [then subsequently] a two-year, professional Bachelor of Laws Degree." ${ }^{203}$ The idea, from both the SAILER staff as well as the Ghanaians involved in this transition, was that law needed to be first studied not vocationally but rather intellectually and academi-

201 See William Burnett Harvey, Law and Social Change in Ghana (1966).

202 The eight others included, D.K. Afreh, W.C. Ekow Daniels, A.N.E. Amissah, Kwasi Gyeke-Dako, J.K. Agyemang, Thomas Mensa, George K. Ofosu-Amaah, and Justice NA. Ollennu. See Letter from William Burnett Harvey to the Vice Chancellor of the University of Ghana (Conor Cruise O'Brien), (Sept. 25, 1963) (on file with author).

$203 / d$. at 2. 
cally; thereafter rigorous professional training could occur. ${ }^{204}$ In his briefings to university officials, Harvey repeatedly touted the credentials of his faculty to perform both tasks. ${ }^{205}$ The Ghanaians, in particular, were clearly accomplished and productive, and for Harvey, highlighting their various feats served as powerful examples from which his superiors and the law students could gain inspiration. ${ }^{206}$

This legal education work might have continued for years had Harvey and his colleagues operated within a vacuum. Like in Ethiopia, however, such was not the case in Ghana. Larger political factors soon impeded the functioning of the law faculty. To begin, the university, by law, fell under the chancellorship of President Nkrumah. ${ }^{207}$ The Vice Chancellor was an Irishman, Conor Cruise O'Brien. O'Brien's long public career would eventually include stints in journalism, civil service, and elected politics. ${ }^{208}$ At the University, $O^{\prime} B$ rien's position ran the gamut from serving as the day-to-day manager of all administrative affairs, the faculty representative to the government, and the final overseer of all student matters. ${ }^{209}$ The relationship between Nkrumah and $O^{\prime}$ Brien was complicated; initially the two worked well together but over time as Nkurmah consolidated his power over both the political and university worlds, $\mathrm{O}^{\prime}$ Brien would become an adversary. ${ }^{210}$

$204 / d$. Also, this view was conveyed during interviews that took place in Accra with a group of faculty members at the University of Ghana Law Faculty, August 9, 2010. See also, interview with two senior, current practicing lawyers, in Accra, who were intimately familiar with the SAILER program and the Ford Foundation's efforts during the 1960s (Aug. 10, 2010).

${ }^{205}$ See Letter from William Burnett Harvey to the Vice Chancellor of the University 4-5 (Sept. 23, 1963).

${ }^{206} \mathrm{See}$ id. (in particular Harvey's description of the Ghanaians contributions to a range of publications, including the nascent University of Ghana Law Journal (heretofore, the Legon Law Journal)).

207 This section will draw on the insightful biography, DONALD H. AKENSON, CONOR: A Biography of Conor Cruise O'Brien 226-54 (1994).

208 See generally id.

${ }^{209} / d$. at 226-54.

${ }^{210} / d$. This is not to intimate that $\mathrm{O}^{\prime} B$ rien did not passionately believe in his views that ran counter to Nkrumah. For a discussion of this point, see id. Also, involved in what O'Brien considered meddling was Ghana's Attorney General Geoffrey Bing, who served from 1957-1961 and then as an advisor to Nkrumah until his being deposed in 1967. Id. at 225. Akenson describes Bing as irritating $\mathrm{O}^{\prime}$ Brien because of "Bing's attempting to insinuate himself into the management of the university." Id. 
The transition of the Gold Coast-born Nkrumah (or as he was sometimes referred to as Osaygefo ${ }^{211}$ ) from an American educated theology and philosophy student to the dominant leader of postindependent Ghana has been discussed at length by various scholars. ${ }^{212}$ Relevant here is that vis-à-vis the university, Nkrumah intervened much more into the affairs of the faculty following an assassination attempt on him in 1963. A special court headed by the Chief Justice of Ghana, Arku Korsah, acquitted three of the five defendants, and in response the President removed Korsah from office later that year. ${ }^{213} \mathrm{O}^{\prime}$ Brien and his university colleagues argued that this action was unconstitutional, and thereafter Nkrumah and his allies viewed (with even more scrutiny) the Ghana faculty as a serious threat to the government's authority. After a series of intimidating measures taken by the President, ${ }^{214}$ in late January of 1964 the government ordered Harvey and his close SAILER colleague, Robert B. Seidman, deported. Through connections Seidman's friends and his wife (the economist Ann Seidman) had with Nkrumah, he was allowed to return to Accra (although Harvey was not); but Seidman left Ghana shortly thereafter for Lagos, Nigeria after learning that a colleague who he believed was behind his deportation soon became dean of the law faculty. ${ }^{215}$

${ }^{211}$ See id. (the term translated from the language Twi means "redeemer," or "leader").

212 See id. at 226-54. See also June Milne, Kwame Nkrumah: A Blography (2006).

213 See Akenson, supra note 207, at 226-54; Robert Justin Goldstein, The New York Times, 20th Century in Review: Political Censorship 260 (2001).

${ }^{214}$ See AKENSON, supra note 207, at 226-54 (as Akenson discusses, in early 1964 another failed assassination attempt was made on Nkrumah. Further, in this discussion that Akenson describes, Nkrumah ordered the closing of the university campus. He sent police forces to intimidate peaceful student protesters. He had faculty detained [e.g., a Briton, Dr. D.G. Osborne and a Ghanaian, Dr. J.C. de GraftJohnson]. And he (Nkrumah) outlined six specific demands on the Vice Chancellor, O'Brien, regarding how the President needed to be more intimately involved in university affairs ranging from teaching appointments to university scholarship to various committee-workings).

215 Following his deportation, Seidman left for Ethiopia, then to Tanzania, and then to Britain before returning briefly to Ghana. See author correspondence with Robert Seidman (July 28, 2011). See also AKENSON supra note 207, at 247-54. Here, as Akenson discusses, it is unclear whether Nkrumah himself ordered the deportation of the two Americans. According to Akenson's account, the security forces appeared to concede to Vice Chancellor O'Brien that Nkrumah did not know about the specific order; indeed in his letters condemning this action to Nkrumah, $\mathrm{O}^{\prime} \mathrm{Brien}$ 
The departures of Harvey and Seidman devastated SAILER's program in Ghana. Although Harvey had convinced the government to allow the remaining SAILER-funded teachers (Vern Davidson, Judith and Michael Thoyer, and Jeremy Harrison, see table 1 above) to finish out the 1963-1964 academic year, for all intents and purposes, substantively and symbolically, Bainbridge and his colleagues concluded that "[f]urther continuance.... [was] impossible without compromising one's intellectual independence." 216

In 1966, Nkrumah's government was overthrown in a military coup while the President was on a visit to North Vietnam and China. Seidman, thereafter, returned to Ghana and received a chaired presidential professorship from the new government. ${ }^{217}$ However, hopes for fully re-launching SAILER's investment in the country were dashed when in April of 1967 another coup occurred, which led Seidman and his family to depart from Ghana. (He would soon take up a faculty appointment at the University of Wisconsin-Madison Law School.218)

The ultimate assessment by Bainbridge of the Ghana project was mixed. On the one hand, he believed that the years in which Harvey was able to lead the school raised the caliber of education and greatly benefitted the students. Indeed, in interviews with Ghanaian SAILER students, this sentiment was corroborated. ${ }^{219}$ Moreover,

states that he hopes that the President did not know about the order and that if he did, then $O^{\prime} B r i e n$ emphasizes that his "continued tenure as Vice-Chancellor would serve no purpose." Id. at 249. Note, as Akenson also discusses, and as confirmed in an interview with Professor Seidman, (Author interview, June 20, 2011), Harvey and Seidman's names were given to the government by their colleague, W.C. Ekow Daniels, who would soon thereafter go on to lead the law faculty as dean. See also BAINBRIDGE, supra note 11, at 35. Note Professor Seidman's wife, the economist Ann Cox Seidman, stayed back in Accra to continue as a lecturer in the economics department. As she noted, they had five young children who were in school (three in the prestigious Achimoto boarding school), and so because of this and her commitment to her students, she remained. (She commuted back-andforth to Lagos, Nigeria, where her husband had taken an appointment on the law faculty there.) Interview with Ann Seidman (June 20, 2011).

${ }^{216}$ See Bainbridge, THE SAILER PROJECT, supra note 9, at 69.

${ }_{217}$ See interview with Robert B. Seidman (June 20, 2011). For details why Seidman wanted to return, see supra text accompanying note 215 (namely, discussing the family reasons that brought him back).

${ }^{218}$ Id. Interestingly, SAILER did opt to fund one teacher for a two year period during this political instability. See Table 1 above in the text, noting David $B$. Bryson's tenure in Accra.

${ }^{219}$ Author interviews occurred on August 8 and August 9, 2010. 
following the 1967 coup, the university faculty hired Dr. Alex A. Kwapong, a highly respected classics scholar, to serve in the central administration. Kwapong sought funding from SAILER and wanted to move the institution in the direction initiated by Harvey. ${ }^{220}$ In addition, the law school saw Thomas Mensah, another well thoughtof scholar, elevated to Acting Dean; and by this time the law faculty was completely staffed by Africans. ${ }^{221}$

Still, Bainbridge expressed angst over the many uncertainties that surrounded legal education within the country. There had been a serious reduction in government financial support for students wishing to pursue a law degree. 222 The Ghana Law School-the institution that was closed because of a general agreement that it was underperforming-reopened..$^{223}$ In fact, to the dismay of the university law faculty, the Ghana Law School soon gained "exclusive jurisdiction over the teaching of Company Law, Evidence, Civil Procedure, Family Law, and Taxation"224_courses.all deemed to be crucial to the curriculum of the university. ${ }^{225}$. These factors and the larger political context were too overwhelming for SAILER. By the end of the 1960s SAILER's on-the-ground efforts all but ended in Ghana. A similar outcome, as will be seen next, emerged in Nigeria as well.

\section{The Case of Nigeria}

With its vast territory, diverse linguistic, ethnic, and religious populations, and its own political upheaval, Nigeria posed arguably the greatest challenge for the SAILER project during the 1960s. The elite segment of the Nigerian bar was already incredibly sophisticated,

\footnotetext{
${ }^{220}$ See Bainbridge, THE SAILER PROJECT, supra note 9, at 69.

221 /d. at 70 .

$222 / d$.

223 Id. at $70-71$.

${ }^{224} / d$. at 71 . Note this feeling of dismay was conveyed to the author by SAILER students in Ghana who knew Dr. Mensah and his other colleagues. Interview with two former Ghanaian SAILER students, who are now prominent lawyers in Accra (Aug. 9, 2010).

${ }^{225}$ The explanation for this shift seems to be that the Ghana Law School was staffed by people who had vested interests and closer allegiances to the government, whereas there remained great suspicion by state leaders towards the faculty at the university. Interview with two former Ghanaian SAILER students, who are now prominent lawyers in Accra (Aug. 9, 2010).
} 
prompting one former SAILER teacher to narrate a story about how when he came to Nigeria in his mid-twenties, fresh out of law school, he had an opportunity to meet with a member of the country's Supreme Court. The Justice informed the American that he was educated in England, as was his father, as were other relatives - to which the American remembered thinking to himself, "What in the world do I have to offer here?"226

But as this young SAILER teacher learned from this Justice, as well as from other accomplished lawyers and judges in the country, many Nigerians affirmatively requested the assistance of the Americans, specifically to help train those aspiring law students who could not afford to travel abroad to study. ${ }^{227}$ Still, as the archival documents show, Nigeria confounded Bainbridge and his colleagues, who had difficulty grasping the complexities of how best to structure the program's objectives. At the 1962 African legal education conference in Ghana, a delegation of Nigerians suggested having Ford fund two law faculties-one in the southern, more Christian region of Ibadan and the other in the north, which was predominantly Muslim. ${ }^{228}$ The Americans initially acquiesced, without doing enough due diligence, and only later came to learn that "two law faculties for Nigeria was unrealistic . ..." 229 Political as well as religious and ethnic factors mandated that law faculties be established in multiple regions. As Bainbridge would write some years later:

As it turned out, Ibadan was the only Nigerian University which never established a law faculty [italics added]. Law [however] was among the first faculties in the other four [already present] universities, Amadu Bello [Zaria], Ife, Lagos, and the University of Nigeria at Nsukka. ${ }^{230}$

Rather than devoting resources to starting new law schools, the SAILER-project opted to work with these pre-existing institutions. Lagos received particular attention from New York, given that it was the capital and political and economic hub of the country. But the

\footnotetext{
226 Interview with former SAILER teacher (June 21, 2011).

227 Id. See also interviews with five different senior lawyers in Lagos, Nigeria who were intimately familiar with the SAILER-project (Aug. 4-5, 2010).

228 See BAINBRIDGE, supra note 11, at 37-39; see also Bainbridge, THE SAILER ProsECT, supra note 9, at 80-88.

229 See BAINBRIDGE, supra note 11 , at 38 .

$230 / d$.
} 
amount of SAILER-support was modest. Between 1962 and 1965, SAILER provided funding for only two faculty lines, Andrew Park and Robert Seidman. The latter came to Lagos from Ghana in 1964. ${ }^{231}$ One reason may have been because the university was already funding foreign scholars on its own, including the well-known British academic, L.C.B. (Jim) Gower to head the law faculty. ${ }^{232}$

With Gower at the helm, beginning in 1962, the law faculty at the University of Lagos (or "Unilag") engaged in a number of initiatives. These included shoring up its library, establishing the Nigerian Law Journal, creating a think-tank called the Institute of Advanced Legal Studies, and hiring erudite Nigerian teachers to bring a scholarly milieu to the university. ${ }^{233}$

Yet overarching politics reared its presence into the Lagos law faculty. In early 1965, the governing body of the university failed to reappoint the sitting Vice Chancellor to another term. ${ }^{234}$ This decision flew in the face of the faculty Senate's imprimatur of the incumbent. ${ }^{235}$ When it later became known that the governing body's replacement was from the Yoruba ethnic tribe-the majority constituency in this part of the country-outrage ensued. ${ }^{236}$ (The incumbent was an Ibo tribe member.) Students went on strike and many faculty members loudly protested; in response the governing body sacked five deans across campus, including Gower. ${ }^{237}$ To protest that move, several law faculty members-Nigerians and Westerners-resigned, including Seidman who by then had received

${ }^{231}$ See Table 1 above; see also interview with Robert Seidman who discussed this modest SAILER support for the Lagos faculty during his time there (June 20, 2011).

232 See short version of curriculum vitae of L.C.B. Gower (on file with author).

233 Interview with Robert B. Seidman (June 20, 2011); see also Bainbridge, THE SAILER PROJECT, supra note 9, at 80. Prior to this post, Gower was Professor Emeritus at Southampton University and had served as a key advisor to the British Department of Trade, the British Institute of International and Comparative Law, and the Nigerian Council of Legal Education. See source cited supra note 232.

234 See BAINBRIDGE, supra note 11, at 40 . The governing body was known as the Provisional Council, and Bainbridge goes into detail about the politics surrounding this controversy. See also Bainbridge, THE SAILER PROJECT, supra note 9; at 80.

${ }^{235}$ See sources cited supra note 234. See also interview with Robert B. Seidman (June 20, 2011).

${ }^{236}$ See sources cited supra note 235.

${ }^{237}$ See sources cited supra note 235. 
permission to return to the law faculty in Ghana. ${ }^{238}$ The university closed for months, leaving great uncertainty as to what might come next.

Indeed what then occurred affected not just the university but everyday life for much of the country. In January of 1966, the military deposed President Nnamdi Azikiwe. Eight months later another coup occurred, placing Yakubu Gowon in charge of the state. ${ }^{239}$ The following year, Nigeria was engulfed in the bloody Biafran War, where the lbo-dominated eastern part of the country attempted to secede from the federation. Even before the war, deep tensions along ethnic lines existed (the Vice Chancellorship controversy at Lagos was just one snapshot); now with actual fighting taking place, there was real question as to what would become of the Nigerian state. ${ }^{240}$

The Biafra War lasted three long years (1967-1970) and placed an enormous strain on the country. Still, though, there remained deep interest among various Nigerian law students and legal professionals to continue to work on legal education in the country. One senior lawyer (who was a SAILER student at the time) explained that focusing on law and education "was a great distraction from the crippling realities that were overcoming the nation." ${ }^{241}$ He sadly remembered though that almost all of the SAILER teachers left Nigeria by the time the war commenced in 1967.242

This lawyer also stated, as did other Nigerians interviewed, that with the virtual end to SAILER within the country, several planned law reform projects were delayed or abandoned altogether. Consider a proposal to develop a Centre for Islamic Studies at Ahmadu

${ }^{238}$ See sources cited supra note 235; see also above text (discussing Seidman's appointment to Presidential Professor at Ghana).

${ }^{239}$ In the late 1990 s, the BBC provided a time-line on the set of Nigerian coups that have occurred during the twentieth century. See After Abacha, Nigeria: A History of Coups, BBC NEWS (Feb. 15, 1999), http://news.bbc.co.uk/2/hi/africa/ 83449.stm. See also, BAINBRIDGE, supra note 11 , at 41.

${ }^{240}$ For a literature on this conflict that cost approximately one million lives, and the Nigerian state more generally, see TOYIn Falola \& MatTHEW M. HEaton, THE History of Nigeria (2008); Daniel Jordan SMith, A Culture of Corruption: Everyday DeCeption and Popular Discontent in Nigeria (2008); Frederick Forsyth, The Biafra Story: The MakING OF A LEGEND (2007). See also After Abacha, supra note 239.

${ }^{241}$ Interview with Nigerian SAN (Senior Advocate of Nigeria) (Aug. 5, 2010).

${ }^{242} \mathrm{Id}$. This point is confirmed by Table 1 above, which shows that one SAILER teacher, Shirley Zabell, the only woman of the group, actually stayed until 1968 before leaving. 
Bello University ( $A B U$ ) in the northern city of Zaria. ${ }^{243}$ Supportive of the Centre were Alan Milner (an Irishman) and Victor Mackinnon (a Scot), who each served as the inaugural and second law faculty deans beginning, respectively, in 1962 and $1967 .{ }^{244}$ There was also backing from the faculty comprised of Americans, Britons, and an East Indian. ${ }^{245}$ Once the war broke out, however, the energy behind making the Centre a top-flight research hub ended. ${ }^{246}$

Other areas of law reform also stalled. There was a continuing legal education project upon which Nigerian educators sought SAILER-assistance. ${ }^{247}$ Bainbridge attempted to organize SAlLERteachers to work on this effort; yet, once again, after the war started it was difficult to find Americans willing to travel to Nigeria for this initiative. $^{248}$

Similarly, Nigerian educators wanted to promote instruction and scholarship in the areas of customary law, indigenous law, and "unofficial" dispute resolution. 249 Bainbridge too believed in the importance of this goal and financially supported projects that involved collecting, sorting, and categorizing materials in these fields. ${ }^{250}$ The difficulty was that while good research work on this front began occurring in certain places, such as at the Islamic institute at $A B U,{ }^{251}$ given the war, there was a limit as to how much progress could be

${ }^{243}$ See Bainbridge, THE SAILER PROJECT, supra note 9 , at 86-88.

244 Id.

${ }^{245}$ Id at 87 (the Americans included one teacher from SAILER and others from programs affiliated with MIT and Syracuse University).

${ }^{246}$ Although it must be noted that SAILER did provide some funds for library support for ABU. BAINBRIDGE, supra note 11, at 104 . Today the Centre exists and has eleven academic staff members, see list of Staff, AHMADU BELLO UNIVERSITY, http://www.abu.edu.ng/unit/vwstaff.php? $\mathrm{t}=\mathrm{i} \& \mathrm{cid}=20 \& \mathrm{cnm}=$ Centres $\& \mathrm{did}=125 \& \mathrm{~d}$ $\mathrm{nm}=$ Centre\%20for\%20Islamic\%20Legal\%20Studieshttp://www.abu.edu.ng/unit/ vwstaff.php $\mathrm{t}=\mathrm{i} \& \mathrm{cid}=20 \& \mathrm{cnm}=$ Centres $\& \mathrm{did}=125 \& \mathrm{dnm}=$ Centre $\% 20$ for $\% 20$ Islamic\%20Legal\%20Studies (last visited Nov, 18, 2011). See also Bainbridge, supra note 9 , at $87-88$.

${ }^{247}$ Interview with two different Senjor Advocates of Nigeria who discussed this plan (Aug. 5, 2010).

248 Id. See generally BAINBRIDGE, supra note 11 , at 112-13.

${ }^{249}$ See BAINBRIDGE, supra note 11, at 113-20.

${ }^{250} \mathrm{ld}$. He also supported this in other countries, including Kenya, the former Tanganyika, Zambia, Sudan, Malawi, and Ethiopia.

251 Id. at 119. 
made. ${ }^{252}$ At the University of Ife's Faculty of Law, the dean, Barbadian-born, Sheffield University scholar O.R. Marshall, was assured by the government that it would fund major research endeavors on local law. ${ }^{253}$ As ethnic tensions started to flare in the mid-1960s and then with the start of the war in 1967, the government redirected its expenditures away from education and towards other internal affairs. ${ }^{254}$

All of these examples underscore the despair many law students felt as the larger political realities adversely affected and ultimately disrupted their educational experiences. Importantly, though, even as foreign teachers and foreign funding dwindled, the Nigerians tried carrying on with their educational and professional obligations. So, for instance, Nigerian students continued to study-and Nigerian teachers continued to teach-customary and indigenous law. Nigerian law faculties held programs that involved training and better preparing judges for the changing world in which they lived. ${ }^{255}$ And Nigerian academics remained present at both domestic and international legal education conferences, some even during violent periods of the Biafran War. ${ }^{256}$

${ }^{252}$ Interview with two different Senior Advocates of Nigeria who discussed this plan (Aug. 5, 2010).

253 Interview with an American SAILER-teacher who was brought to Ife for this purpose (June 22, 2011).

${ }^{254} \mathrm{ld}$. (who noted that he left his SAILER-post one year earlier because of the suspension in funding and because of the increased security risk that was mounting in the region). Another problem was that the facilities at the actual Ife campus took several years to complete (six years between 1961 and 1967). Students and faculty met on the University of Ibadan campus, which was dilapidated, "some 50 odd miles [away] and a journey of almost two hours ...." See Bainbridge, THE SAILER PROJECT, supra note 9, at 83.

${ }^{255}$ See e.g., Bainbridge, supra note 9 , at 113.

${ }^{256}$ For example, Nigerian scholars particjpated in an international conference on administrative law in Nairobi, Kenya in 1971, just after the war ended. See BAINBRIDGE, supra note 11, at 98. A major conference in Lagos took place in August of 1970 , with the focus being on criminal punishment occurring by the then-military government. Its provocative nature highlighted that Nigerian legal academics sought to confront and challenge what they perceived as human rights violations, in spite of the potentially dangerous ramifications of doing so. $I d$. at 161-62. One year prior, in Ghana, a research workshop took place that involved a small delegation from Nigeria. $l d$. at 157 . And prior to the war's commencement, but during periods of great ethnic tension, in 1965, the Nigerian Law Teachers Association meeting was held in Ibadan to discuss issues of pedagogy. However, because of an eventual lack of funding, future such meetings were placed on hold. Id. at 164-65. 
In 1970 the bloody civil strife finally came to an end, with a projected one million people dead in the tragic process. ${ }^{257}$ As the country recovered from this devastation it remained under the same military control as before the conflict-that is until another coup occurred in 1975 led by Murtala Muhammed, who himself was murdered in 1976 and then replaced by Olusegun Obasanjo. 258

The political instability in Nigeria as well as in other parts of Africa during the late 1960 s prompted SAILER-officials to change direction in how they approached legal education on the continent. Specifically, the program increased the number of African legal professionals it funded to come to the United States. This shift in focus is examined in the next and final section.

\section{IV. "WE CAME TO AMERICA-AND WE TAUGHT THEM"259}

In 1967, Ford established a new funding wing in New York, the International Legal Center (ILC). ${ }^{260}$ Inaugurated by Ford-president McGeorge Bundy, the ILC centered on providing financial support to developing nations modernizing and democratizing their legal systems. ${ }^{261}$ Recipients could include public institutions (including law schools), non-governmental organizations, and those hosting conferences and rule of law programs. ${ }^{262}$ The ILC also pledged to support American law schools, American lawyers, and American faculty members who wished to help "make legal education, the legal profession and the substance of law ... more relevant to the development needs . . " 263 of emerging countries. Finally, the ILC

${ }^{257}$ Much of these deaths occurred from the fact that people starved. See After Abacha, supra note 249.

258 /d.

259 This was a quote from Ghanaian who received a fellowship to study in the United States. He is now a senior lawyer in Accra. Interview (Aug. 9, 2010).

${ }^{260}$ See International Legal Center, For Release Document, (archival document for Ford Foundation) (June 13, 1967). The start-up funding for the ILC was three million dollars, provided by Ford. See GARDNER, supra note 9 at 48-49; 126-145.

$261 / d$, at 2.

$262 / d$, at $2-4$.

263 /d. at 3 (describing, in particular, the ILC's early program to help Chile, but emphasizing later in this release how this was the goal of the Center more generally. Furthermore, the President of the ILC, John Howard, emphasized: "[o]ne fact about this program-and this is true of all our activities-is of central importance .... We are not trying to export the United States system of laws to another country."). 
instituted a plan to bring foreign law students and legal professionals to the United States to study.

That much of SAILER's work dovetailed with the mission of the new ILC raised questions as to how the two would co-exist. To reconcile this matter, Ford decided to place SAILER within the ILC and to name Bainbridge as the "Director for Africa." 264 Whereas SAILER's focus between 1962 and 1967 involved "the sending of more than fifty American lawyers to help staff new law faculties in ten African countries," 265 the emphasis changed after the ILC emerged. Between 1967 and 1975 less than a third of that number received ILCfunding to travel to the continent. ${ }^{266}$ As the above discussion highlights, macro-political factors across Africa caused this reduction, which thereby resulted in a concerted shift in strategy by the Americans. During this same time period, the SAILER-ILC program supported nearly one-hundred fifty legal professionals from seventeen different African countries to travel to the United States. ${ }^{267}$

The person named to head the ILC was John Howard. Ford created the ILC after a deliberate decision-making process, but its establishment was also partly a farewell gesture to Howard for the sixteen years of service he gave to the organization. ${ }^{268}$ Experienced

264 Id. at 5.

$265 / d$. at 3-4.

${ }^{266}$ See International Legal Center Newsletter 3 (Aug. 1975) (on file with author). Although, see BAINBRIDGE, supra note 11, at 178 (noting that between 1967 "to April 1,1972 , the SAILER Project has assisted or recruited 116 law teachers or lawyers" to work in Africa. This number is confusing as is the wording, because the data do not indicate whether "assisted or recruited" means that the New York office funded Americans to work in these different African countries, or if it hired local Africans onto these respective law faculties, or both. On page seventy-four of BAINBRIDGE, supra note 11 , at n.1, it might appear that it is the first option. However, the ILC data is unambiguous that between 1967 and 1975 it funded sixty-two Americans to teach overseas, twenty-four in Latin America and the Caribbean, twenty-two in Asia and the Middle East, and only sixteen in Africa. One possibility of reconciling this difference between BAINBRIDGE, supra note 11, at 178, and the ILC's numbers is that on page one of the latter's document, it states: "[n]ot included in this Newsletter are the ... several Fellows who served in Africa with financial assistance from USAID." Perhaps, then, the BAINBRIDGE, supra note 11, at 178 , figure refers to SAILER working with the U.S. Agency for International Development to help Americans travel to Africa).

${ }^{267}$ See African Scholars Supported by the International Legal Center (Dec. 1974) (on file with author).

${ }^{268}$ For an intimation of this point, see Francis X. Sutton's Tribute to John Howard (Dec. 31, 1999) (revised January 13, 2000) (on file with author). For a reiteration of this point, see also interview with Sutton (Dec. 7, 2010). 
with Ford's bureaucracy, Howard's most well-known contribution during his Ford-years was on its International Training and Research (ITR) program. The ITR funded international studies projects mainly at American universities - in the aggregate amount of roughly 270 million dollars-from the mid-1950s throughout much of the following decade. ${ }^{269}$ Together Howard, Bainbridge, and Terry Wooda former IIE official who joined the ILC when it opened-worked on what might be viewed as "SAILER 2.0 " beginning in 1967.270

Of the almost one hundred fifty Africans assisted by SAILER-ILC, the archival data indicate that between 1967 and 1975, eightyseven pursued graduate degrees, mostly LL.Ms. ${ }^{271}$ SAILER-ILC also funded students to visit the University of Wisconsin, during the summers of 1971 and 1972, to enroll in a workshop on law and development run by Robert and Ann Seidman. ${ }^{272}$ Additionally, SAILERILC supported Africans to visit universities for other research purposes, to attend short-term courses, or to spend time observing American court proceedings. ${ }^{273}$

Interviews with the Americans and Africans affiliated with the SAILER-ILC program indicate an agreement that these foreign visits offered multiple benefits. Given the political tumult in much of Africa during this time, the visits gave legal professionals from these

269 This figure and the discussion of Howard's contributions at the ITR can be found in the tribute written to him by Francis X. Sutton, supra note 268.

${ }^{270}$ Interview with Terry Wood (Dec. 8, 2010). SAILER 2.0. is a term that the author has labeled the program, once it fell under the auspices of the ILC.

${ }^{271}$ See African Scholars Supported by the International Legal Center document, supra note 267 (noting of the 87 students, per country the number of students was: Ethiopia 13, Ghana 17, Kenya 10, Lesotho 1, Liberia 2, Malawi 1, Nigeria 14, Sudan 3, Tanzania 7, Uganda 12, Zaire 3, and Zambia 4. Of the 87 students, SAILERILC provided funds for the pursuit of the following degrees (note, this number is higher than 87 because some students sought multiple degrees): 68 LL.Ms; 18 S.J.Ds; 3 M.L.Ss; 2 J.S.DS; 2 M.L.Is; 1 Ph.D.; 1 M.C.L.; and 1 M.C.J. In terms of universities, these institutions received the following number of SAILER-ILC graduate candidates for the following degrees (note the number here exceeds 87 as well, because some of the same students pursued different degrees at different institutions): California-Berkeley 2 LL.Ms, 1 S.J.D.; Chicago: 1 S.J.D.; Columbia: 15 LL.MS, 2 S.J.Ds, 2 M.L.Ss; George Washington: 1 LL.M.; Harvard: 20 LL.Ms, 2 S.J.Ds, 1 J.S.D; Illinois 1 LL.M.; Michigan: 1 S.J.D., 1 M.L.S.; New York University: 2 LL.Ms, 1 S.J.D.; Northwestern 1 LL.M.; Pennsylvania: 1 LL.M., 1 M.C.L.; Queens (Ireland): 2 LL.Ms; Stanford: 1 LL.M.; Temple: 2 LL.Ms; Wisconsin 2 M.L.Is; 1 Ph.D.; Yale 21 LL.Ms, 7 S.J.D.).

\footnotetext{
${ }^{272}$ See id.

273 /d.
} 
affected countries a safe place to concentrate on their studies. ${ }^{274}$ Of the twenty-one Ethiopians, for example, who received SAILER-ILC funding for one purpose or another, nearly half were in the United States at some point in 1973, just prior to the violent revolution that took place within the country..$^{275}$ From Nigeria, where SAILERILC also supported a total of twenty-one legal professionals, ten came for periods during the Biafra War, and the remaining were present in the United States during the military rule following the conflict. 276

Another benefit the Africans enjoyed were the academic resources available to them. Especially for those who came to the universities, several respondents noted that the presence of physically-sound buildings, filled libraries, and engaged and learned teachers all contributed to why they felt the experience was so rewarding. Some did state they encountered various forms of racism in certain situations, and while these episodes were distressing, they were counterbalanced by the positive relationships they made in and out of the classroom.

The other extremely important benefit was that, especially for those who earned specific degrees, having such a paper credential provided a comparative advantage in terms of employment back in their home countries. Yet, a tension existed as well. In many African countries sentiments of nationalist pride and attitudes of eschewing of all things Western permeated the political and social landscapes. At the same time, having degrees from places like Yale, Harvard, and Columbia (the three institutions that granted the most LL.Ms and S.J.Ds to SAILER-ILC funded Africans) provided immense cachet. One prominent Nigerian lawyer commented how ironic it was that "for as much as many of them [his colleagues at the bar] chided America, they would have loved to have my Yale degree." 277 A Ghanaian senior lawyer was even more direct: "My Yale degree gave me more legitimacy as a lawyer here in Ghana than any other Ghanaian degree could."278

\footnotetext{
274 See author interview with a senior legal educator in Ghana (Aug. 11, 2010).

275 See African Scholars document, supra note 267, at 2-5.

276 See id. at 12-14.

277 Interview with Senior Advocate of Nigeria (Aug. 5, 2010).

278 Interview with Ghanaian lawyer (Aug. 9, 2010).
} 
With that said these two lawyers, as well as several other Africans, hastened to point out the contributions they made to their American hosts. The American interviewed for this project concurred. First, as a result of the visits, collaborative work-products emerged in the form of articles, books, and jointly-organized conferences. The 1971 and 1972 Wisconsin workshops, for example, served as the planning grounds for an international conference held in Zambia in 1974 on the legality of copper mining, which then resulted in a 1975 publication on the intersection of law and natural resources in Africa. ${ }^{279}$

Second, and related, the Africans helped to intellectually diversify the classroom and broaden the perspectives of those who were teaching them. As one American instructor noted, "by engaging with our students and colleagues, we learn[ed] more-and deepen[ed] our insights into-the problems and possibilities of using [for instance] institutional legislative theory and methodology to overcome the institutional obstacles that too often block effective, people oriented development." 280 Otherwise put, the African visitors helped situate context for the teachers and students in ways that the Americans-even those who had spent a great deal of time in Africa-had difficulty doing on their own.

Third, the Africans who came to the United States served as key bridges between different constituencies in their own countries and the Americans with whom they interacted. Many of these relationships that developed resulted in the Africans coordinating enriching initiatives for the Americans such as government delegations, visiting professorships, and student exchanges. One relationship, in particular, was especially noteworthy. In 1975, Temple University Law School, based in north Philadelphia, launched a study-abroad program at the University of Ghana at Legon. ${ }^{281}$ Temple had two Ghanaian LL.M. students a few years earlier, and its Dean, Peter Liacouras, along with Professor Peter Sevareid, started this program. ${ }^{282}$ However, the project came to fruition in large part because

\footnotetext{
${ }^{279}$ See author correspondence with Ann Seidman (June 30, 2011) (on file with author).

$280 / d$.

281 Interview with retired Temple University Professor Peter Sevareid (June 30, 2011). Sevareid was a SAILER-ILC fellow in Nairobi between 1968-71 at the Kenya Institute of Administration and then went to Temple as a faculty member in 1972. $282 / d$.
} 
a Ghanaian in Accra-John Atta Mills, the current president of Ghana-at that time served as the main liaison for this project. Mills, a former Fulbright and SAILER-ILC fellow, earned a graduate degree from Stanford in the early $1970 \mathrm{~s} .{ }^{283} \mathrm{He}$ was a faculty member at the University of Ghana in 1970s, and he played a pivotal teaching role in the Temple study-abroad program. ${ }^{284}$ (Mills also came to Temple as a visiting professor in 1978.)

Temple's program ran successfully for several years but then ended, perhaps not surprisingly, because of macro-political factors. In 1979, Jeremiah (Jerry) Rawlings led a military coup that overthrew the sitting government. Although the Temple program continued that year and the year after, in 1981 Liacouras and Sevareid suspended operations. Their decision was based on a food shortage that occurred within Ghana following the coup. ${ }^{285}$ There was also on-going political instability; Rawlings had allowed scheduled elections to proceed in 1979, and the result was that Hilla Limann and his People's National Party came to power. But at the end of 1981 Rawlings seized power again, toppling Limann and assumed direct control over the government. ${ }^{286}$ While Temple's presence in Ghana ended, its affiliation with the Ghanaians did not. In 1982, the law school welcomed Samuel Gyandoh, the Dean of the University of Ghana Law Faculty to its campus, where he remained as a professor for the next two decades. ${ }^{287}$ Gyandoh was a prominent constitutional law professor in Ghana; he had earned an LL.M. at Yale through SAILER-ILC. ${ }^{288}$ However he had run afoul of the regime, particularly in his criticism that the 1981 coup was unconstitutional. Worries of reprisal led to Gyandoh fleeing, and the place where he went was Temple. As he noted, the institutional closeness that had

\footnotetext{
283 See African Scholars document, supra note 267, at 7.

284 Interview with retired Temple University Professor Peter Sevareid (June 30, 2011).

$285 / d$.

${ }^{286}$ For a discussion of the Rawlings regime and this period, see KEVIN SHILLINGTON, The GHAna Revolution (1992); John L. Adedji, The Legacy of J.J. Rawlings in Ghanaian Politics, 1979-2000, 5 Afr. Stud. QuARTERly 1 (2001), available at http://www.africa. ufl.edu/asq/v5/v5i2a1.htm.

287 Interview with retired Temple University Professor Peter Sevareid (June 30, 2011); see also interview with Samuel Gyandoh (Aug. 9, 2010).

${ }^{288}$ African Scholars Supported by the International Legal Center document, supra note 267.
} 
developed between Legon and Temple made the transition possible; ${ }^{289}$ and given his scholarly reputation the latter was delighted to hire him. ${ }^{290}$

By 1976, Ford decided to re-focus its financial priorities towards other areas, and as such support for the SAILER-program within the ILC ended. Nevertheless, as this preceding example with Temple highlights, the relationships that emerged from this initiative continued for years after. However, as SAILER ended, strong criticisms arose questioning the "law-and-development" model and the Ford program. This study concludes by discussing this critique.

\section{CONCLUSION}

As SAILER wound down, the ILC leadership curiously asked a law student from Berkeley, Robert Listenbee, who was a summer intern, to provide a comprehensive analysis of the entire program. Listenbee had done some previous volunteer work "in secondary education and rural development projects in East Africa." 291 Yet Listenbee, by his own admission, "was not directly or indirectly involved with the project nor did he interview a representative cross section of its major participants." ${ }^{292}$ Conspicuously absent was the fact that Listenbee saw not one of "the [SAILER] programs in action" 293 on the African continent, making the decision to place him in charge of evaluating such a long-standing, majorly-funded initiative that much more perplexing. In fact, two respected senior Ethiopian lawyers who were students at Haile Selassie University during the early 1970s - and had learned that an evaluation was completed by someone who never witnessed what occurred in Addis-remarked how astonished they were by this decision. As one of these lawyers

\footnotetext{
289 Interview with Samuel Gyandoh (Aug. 9, 2010).

290 Interview with retired Temple University Professor Peter Sevareid (June 30, 2011).

${ }^{291}$ See Robert Listenbee, Close-out Evaluation of the SAILER Project, Ford Foundation Memorandum 1 (Aug. 27, 1975) (on file with author).

292 See id. at 1.

${ }^{293}$ See internal Ford Foundation memorandum from Robert H. Edwards, then head of the Mid-East and Africa division (July 18, 1977) (on file with author). For his report, Listenbee relied on past Ford documents and selected interviews with Ford officials, American SAILER teachers, and Africans who were in the U.S. on SAILER-ILC fellowships. See also second report by Robert Listenbee, Evaluation of MEA-ILC Programs (Apr. 1976) (on file with author).
} 
asked, "if they [Ford officials] wanted to know what we thought, why didn't they hire someone to come here and ask us?"294

Instead, the ILC selected Listenbee, and although he lacked the full set of on-the-ground facts, he nevertheless submitted two separate evaluations that can only be described as blistering in their assessments. The first report covered SAILER 1.0-from 1962-1967, with the second assessing SAILER 2.0, when the ILC took over the program. The two reports, which Listenbee suggested reading together, ${ }^{295}$ began by outlining the history and facts of the SAILER. ${ }^{296}$ From there, Listenbee proceeded to provide his critique, summarily labeling SAILER as "imperialistic,"297 "chauvinistic," 298 and inhering with "evils." 299 (The particular reference to American chauvinism appeared repeatedly in his assessment. ${ }^{300}$ ) While he conceded that the American-teachers were enthusiastic, hard-working, and competent, ${ }^{301}$ he determined that SAILER had unrealistic goals, little impact, and was obsessed by displacing the British legal influence on the African continent with its own American agenda..$^{302}$

The highly-charged rhetoric continued in the second part of the evaluation. Much of the focus here turned on his critique of the African Law Reports (ALR), which SAILER had promoted. Once again, Listenbee was scathing-arguing that the "long term results have been disastrous and predictably so." 303 For Listenbee, the underlying policy rationale for the ALR was flawed, because in his view it sought to shape African law in a way that would advance the Americans' agenda. ${ }^{304}$

\footnotetext{
${ }^{294}$ Interview (Aug. 7, 2010).

${ }^{295}$ See Listenbee, Evaluation of MEA-ILC, supra note 293, at 1.

${ }^{296}$ See Listenbee, Close-out Evaluation of the SAILER Project, supra note 291, at 1-4.

$297 / d$. at 5.

$298 / d$.

$299 / d$.

$300 / d$. at 7 (noting that " $[t]$ he men who promoted the rule of law were chauvinistically American, cynically anti-British and filled with a missionary certitude about the value of democracy for African nations.").

$301 / d$. at 5.

${ }^{302} / d$. at 5-9. See GARDNER, supra note 9 at 240-83.

${ }^{303}$ See Listenbee, Evaluation of MEA-ILC, supra note 293, at 5.

${ }^{304} / d$. at 6 (noting also that there was great expense for Africans to afford such material).
} 
Listenbee additionally found fault with the fact that so few American law schools opened African law centers, even though SAILER and the ILC made this a policy priority. Too little funding from Ford and a lack of vision on the part of SAILER and ILC officials contributed to why law schools did not embrace this idea. ${ }^{305}$

Overall, Listenbee believed that the entire initiative was hindered by the fact that people like Bainbridge, Howard, and their colleagues simply could not face the reality that Western intervention in places like Africa had real limitations. Try as they might, these Americans would always be disconnected and that Ford continued privileging this fundamentally flawed program without using objective metrics for assessment only perpetuated an illogical policy. ${ }^{306}$

Much of Listenbee's empirics for writing his evaluation came second-hand, mainly from a written summary by William Herman, a Ford program officer who spent six weeks in Africa in $1970 .{ }^{307} \mathrm{Her}$ man himself wrote a memo in 1977 evaluating Listenbee's critiques, in which he agreed with the latter's ultimate conclusions, although he found that certain objectives were met. ${ }^{308}$ But ultimately Herman recommended discontinuing the funding for the ILC. ${ }^{309}$

Later that year, Francis Sutton, one of the architects of SAILER and upon whom Listenbee interviewed for his reports, provided a different perspective. Sutton conceded that serious American chauvinism existed, but he noted that the Listenbee evaluation did not represent how he originally conceived of the program. ${ }^{310} \mathrm{He}$ rejected the charge that he was anti-British, anti-European, or that he promoted a purely American type of law school model in Africa. ${ }^{311}$ To the contrary-Sutton championed and helped approve a major grant for Tanzania, which had a law school that was staffed mainly

$305 / d$. at 7-8.

$306 / d$, at $8-12$.

${ }^{307}$ Id. at 9; see also W.A. Herman, Close out of grants 680-0132A, B, and C to the International Legal Center and 620-0923, A, B, C (Mar. 30, 1977) (on file with author).

308 See Herman, supra note 307, at 1-3 (noting that Americans went to Africa, that Africans came to the U.S, and that more people in the U.S. had a greater interest in Africa "must be considered accomplishments.").

${ }^{309}$ Id. at 4.

310 Memo from Francis Sutton, Institute of International Education, Strengthening of African Legal Education, 62-293 (Aug. 29, 1977) (on file with author).

$311 / d$. at 2. 
by British-trained lawyers. ${ }^{312}$ Consider also that SAILER strongly backed L.C.B. Gower and O.R. Marshall to head law faculties in Nigeria, and that the American teachers in Accra worked closely with the university's Irish-born and educated Vice Chancellor. In other places too, like Ethiopia and Sudan, the faculties reflected a cosmopolitan, rather than provincially-American, outlook, as evidenced by those with whom the Americans interacted and worked. ${ }^{313}$

Sutton's rebuttal underscored a more fundamental problem with Listenbee's analysis in that it failed to take into account the layered natured of cultural pluralism in Africa. As discussed earlier, in many places legal education was affected by a range of racial, tribal, religious, and linguistic sensitivities. Listenbee's report said little about these cross-cutting dynamics. Note the case of Kenyan-born and Oxford-educated Professor Yash Ghai. Ghai, whose grandparents came from North India, was on the faculty at the University of Dares-Salaam in the 1960s and then dean from 1969-1970. Thereafter, he served as a visiting professor at Yale, a SAILER-ILC fellow in Uppsala, Sweden, and since then, he has gone on to become one of the world's foremost authorities on comparative law, legal education, and constitutionalism. ${ }^{314}$ Ghai's writings are broad, deep, and nuanced; in no way would they, along with his experiences and intellect, fit into the simplified categories presented by Listenbee. The same can also be said about Professor William Twining, a Ugandanborn Briton who has made enormous contributions to both African and Western legal thought. ${ }^{315}$

\footnotetext{
$312 / d$.

${ }^{313} / d$. at 2. Supplemented with author interview of Francis Sutton (Dec. 7, 2010).

314 For a brief background on Ghai, see his Professor Emeritus website at the Faculty of Law, THE UNIVERSITY OF HONG KONG, http://www0.hku.hk/law/faculty/staff/ ghai_yash.html (last visited Nov. 18, 2011). See also Yash Ghai, Co-Investigator, ETHNICITY AND DEMOCRATIC GOVERnANCE, http://www.queensu.ca/edg/members/ researchers/ghai.htmlhttp://www.queensu.ca/edg/members/researchers/ghai.html. (last visited Nov. 18, 2011). Moreover, Ghai also provided feedback to Bainbridge on his 1972 SAILER book, see BAINBRIDGE, supra note 11, at iv.

315 In Law and Justice in Tanzania: Quarter Century of the Court of Appeal 5 n.3-4 (Chris Maina Peter \& Helen Kijo-Bisimba eds., 2007), the editors in the introduction provide a valuable bibliography of the various legal education, scholarly contributions made by, respectively, Ghai and Twining. For a select sample, see e.g., Yash Ghai, Legal Radicalism, Professionalism, and Social Action: Reflections on Teaching in Dar es Salaam, in LEgaL RADICALISM: REFLECTIONS ON TEACHING LAW aT THE UNIVERSITY OF DAR ES SALAAM (Issa Shivji ed., 1986); Yash Ghai, The Rule of Law: Legitimacy and Governance, 14 INT'L J. SoC. L. 179 (1986); Yash Ghai, Law, Development, and African
} 
The point is that much of Listenbee's evaluation was too blunt. ${ }^{316}$ Given his own admitted lack of substantive bona fides regarding SAILER, it might be enough to dismiss his report without further discussion. However, some points he raised do deserve recognition. Listenbee rightly noted that demographically the program lacked diversity. There were unfortunately too few women and too few minorities who comprised SAILERS' staff. ${ }^{317}$ Regardless of how well the intentions were, the reality remained that Africa had endured years of colonial rule. Even among those Africans who stated how much they benefitted from SAILER 1.0, there was a sense that having-as one respondent discussed-only white men lecturing to African students in a hierarchical manner felt too eerily similar to the previous era. ${ }^{318}$ Related to this, most of the American SAILER-teachers had little to no knowledge of Africa prior to their being dispatched..$^{319}$ They were recently-minted law graduates, with minimal publications and hardly any work or teaching experience. It would be unusual to place such individuals in front of American law students; that they were "good enough" for the Africans provided an understandable sense of negativity from SAILER-critics. ${ }^{320}$

Scholarship, 50 MOD. L. REv. 750 (1987); William Twining, Legal Education within East Africa, EAST AfRICA TODAY (1986); William Twining, The Camel in the Zoo, in LEGAL Radicalism: Reflections on Teaching Law at the University of DaR es SalaAm (Issa Shivji ed., 1986).

${ }^{316}$ Moreover, there are quotations and references within his report (specifically, supra note 296) from people like Burnett Harvey, Cliff Thompson, and Robert Seidman that come off as clearly supportive of his (Listenbee's) position that these academics were grossly anti-British and pro-American. However, as seen above, their views and perspectives were much more subtle and nuanced than Listenbee acknowledges.

317 Id. at 11 (although noting that "this was due more to the sexist and racist policies of higher education in American than to the Project's recruitment efforts."). See also Richard L. Abel, AmERICAN LAWYERS 74-112(1989) (noting that during this era there were relatively few women and minorities who were matriculating from law schools).

318 Interview with former SAILER-student (Aug. 7, 2010).

${ }^{319}$ See Listenbee, supra note 291, at 11-12.

${ }^{320}$ Although consider that from these SAILER-positions, several of these young (and still relatively inexperienced) SAILER-teachers went straight into American law teaching, often at very elite institutions. Author correspondence with Professor Richard Abel (Aug. 16, 2010). The American law schools that hired these SAILERteachers perhaps saw this Africa experience as crucially important, in a way that "visiting assistant professorships" (VAPs) are seen today by many appointments 
By the end of 1977, Ford's funding for SAILER-ILC ceased. In 1986; a reunion of those involved with SAILER was held in Harriman, New York. Over fifty people affiliated with the project attended and the transcripts from that event indicate that it was a celebratory affair with the participants providing laudatory speeches on their various experiences in Africa. ${ }^{321}$ Nevertheless, these two preceding critiques resonated with and affected some of those present at the program, including Sutton. In his remarks, Sutton too praised SAILER's efforts, and he argued that the motivation for launching SAILER lay in that genuine concern to assist those African nations that requested aid. ${ }^{322}$ The SAILER teachers who worked in Africa gave years of their lives for a cause that centered on promoting the rule of law-and the participating African partners also believed in this same principle. ${ }^{323}$ As he emphasized, Ford and these emerging African states were enthusiastically caught up in a shared "Zeitgeist," 324 whichmore than imperialism or chauvinism-may have led to certain "errors and follies" 325 that occurred.

At the same time, it is clear from his remarks that Sutton remained troubled and somewhat stung by what had been said in the years before, not just by Listenbee but more generally by a critical law-and-development literature that had emerged in the $1970 \mathrm{~s}^{-326}$

committees. Also, at the first Conference on Critical Legal Studies in Madison in 1977, a number of the participants had previously been teachers, researchers, or aid-workers in developing nations. id.

${ }^{321}$ See Twenty Years After, supra note 125.

322 Id. at 21-24.

$323 / d$.

$324 / d$. at $23-24$.

$325 / d$. at 23.

$326 / d$. at 24. In 1977, the American Journal of Comparative Law published two significant articles that discussed this scholarly critique and outlined the literature written by the critics to that point. See John $\mathrm{H}$. Merryman, Comparative Law and Social Change: On the Origins, Style, Decline and Revival of the Law and Development Movement, 25 AM. J. CoMp. L. 457 (1977); Elliot M. Burg, Law and Development: A Review of the Literature \& a Critique of Scholars in Self-Estrangement, 25 AM. J. COMP. L. 492 (1977). For arguably the most important article of this period (which Elliot Burg refers to in his title and article), see David Trubek and Marc Galanter, Scholars in Self-Estrangement: Some Reflections of the Crisis of Law and Development Studies in the United States, 4 WiSC. L. REv. 1062 (1974). See also, David M. Trubek \& Alvaro Santos; The New Law and Economic Development: A Critical APPRAISAL (2006). 
He specifically addressed these assessments as having "excesses"327 and of being "unduly severe" 328 and he refused to waver from his position. As he stated:

We were no doubt more easily optimistic than we ought to have been. But l am sure we were not wrong to try what we did. It would indeed have been pusillanimous and wrong not to have tried. And certainly our objectives were sound ones. ${ }^{329}$

In the end, what can be said is that SAILER - issues and all-was a unique program Ford undertook during the post-World War II era. Unlike Ford's parallel programs on legal education, ${ }^{330}$ SAILER had a sustained a commitment in Africa by immersing its staff in the local environments for extended periods of time. The SAILER-teachers were not "parachute experts" who flew in, doled out advice, and then left. Instead they were dedicated (albeit sometimes naïve and inexperienced) individuals who entrenched themselves in their communities and indeed tried to do their best serving people who they believed wanted their assistance. While larger political forces may have affected their ability to make a long-term impact, the evidence marshaled above shows that among the Africans with whom they interacted, the SAILER-teachers by-and-large had a positive influence. In sum, as academics, bar association leaders, funders, and government officials today contemplate how to address questions of legal education, particularly within modernizing and emerging nations, they might well wish to consider the SAILER-experiment and the lessons from it before enacting specific policy initiatives.

\footnotetext{
${ }^{327}$ See Twenty-Years After supra note 125 at 24.

328 Id.

$329 \mathrm{ld}$.

${ }^{330}$ See e.g., its program in India, Krishnan, supra note 5, or its programs involving Turkey, Egypt, Pakistan, West Germany, supra note 6.
} 